Summer 2015

\title{
Potential Exit from the Eurozone: The Case of Spain
}

Antonio Estella

University Carlos III of Madrid, noriegas@der-pu.uc3m.es

Follow this and additional works at: https://www.repository.law.indiana.edu/ijgls

Part of the European Law Commons, International Law Commons, and the Transnational Law

\section{Commons}

\section{Recommended Citation}

Estella, Antonio (2015) "Potential Exit from the Eurozone: The Case of Spain," Indiana Journal of Global Legal Studies: Vol. 22 : Iss. 2 , Article 4.

Available at: https://www.repository.law.indiana.edu/ijgls/vol22/iss2/4

This Symposium is brought to you for free and open access by the Law School Journals at Digital Repository @ Maurer Law. It has been accepted for inclusion in Indiana Journal of Global Legal Studies by an authorized editor of Digital Repository @ Maurer Law. For more information, please contact rvaughan@indiana.edu.

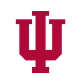

JEROME HALL LAW LIBRARY INDIANA UNIVERSITY Maurer School of Law
Blooming ton 


\title{
Potential Exit from the Eurozone: The Case of Spain
}

\author{
ANTONIO ESTELLA*
}

\begin{abstract}
According to a recent opinion poll that covered seven members of the Eurozone, Spain would be the Member State of this group that is most in favor of leaving the euro. In this public opinion context, and above all since the summer of 2012, debate has been growing in this country about the prospects of its exiling the European Monetary Union. In this article I argue that there are good reasons for taking this debate seriously. Using Spain as a case study, I analyze what the determinants of this decision could be. In particular, I analyze the economic determinants that could condition a decision in this direction. I conclude that in the current situation, a Eurozone member's decision to leave the common currency would be conditioned, in economic terms, above all by time and fairness. Therefore, a key element that a member of the Eurozone would have to take into account when considering whether to leave the euro would be twofold: 1) the extent to which this decision would prompt a faster adjustment; and 2) the extent that exiting would cause a fairer distribution of the costs of the adjustment.
\end{abstract}

\section{Public Opinion and Spain's Membership in the Eurozone}

In opinion poll after opinion poll, Spain emerges as the member of the Eurozone most in favor of exiting the common currency. For example, according to the 2013 edition of the Marshall Fund "Transatlantic 'Trends," 30 percent of Spaniards would be in favor of this option (see Table 1 and

* Jean Monnet Professor ad personam of Law and European Economic Governance and Professor of Administrative Law, University Carlos III of Madrid. A longer version of this article was published by the EUI Robert Schuman Center for Advanced Studies under the title "Determinants of Spain's decision to leave the European Monetary Union." See RSCAS $2013 / 56$.

Indiana Journal of Global Legal Studies Vol. 22 \#2 (Summer 2015)

(c) Indiana University Maurer School of Law 
Figure 1, infra pp. 338-39). ${ }^{1}$ It is essential to note that in the previous edition of this poll in 2012, 27 percent of Spaniards wanted to leave the Eurozone. ${ }^{2}$ Therefore, in just one year the percentage of Spaniards that would want to see Spain exiting the Eurozone had increased by three points. The results of this poll are consistent with domestic polls that regularly ask Spaniards about this issue. ${ }^{3}$

This result is indeed noteworthy for three reasons. First of all, Spain has traditionally been one of the most pro-European Member States of the European Union. Secondly, although Spain is undergoing profound economic hardship, this situation cannot be compared to that of Member States similar to Spain (except in the field of unemployment). And thirdly, but no less importantly, the country has been able to avoid a full bailout. Accordingly, the feeling that the country has been taken over by the Troika is probably less intense than in other Member States that have received a full bailout. One would assume that these circumstances would attenuate Spain's blame on Europe in general and on the euro in particular. However, the opposite seems to be the case.

Talk of Spain's exit has been going on since at least June 2012. At that time, the Spanish risk premium was skyrocketing. Public media reported that in a number of meetings between the recently elected Popular Party government and other European governments - in particular the German government-Spanish top officials threatened Spain's exit if specific assistance measures were not taken. ${ }^{4}$ It is impossible to verify the extent

1. See Transatlantic Trends: Key Findings 2013, GERMAN MARSHALL FUND OF THE U.S. (2013), http:/trends.gmfus.org/files/2013/09/TT-Key-Findings-Report.pdf, at 25 [hereinafter Transatlantic Trends 2013]. Interestingly, the question on Euro-exit was removed from the survey in its 2014 edition. See Transatlantic Trends: Key Findings 2014, GeRMAN MARSHALL FUND OF THE U. S. (2014), http://trends.gmfus.org/files/2012/09/ Trends_2014_complete.pdf [hereinafter Transatlantic Trends 2014]. Therefore, the question of whether the nationals of a Eurozone member would prefer to stay or leave the euro was only made for the 2012 and 2013 editions of this survey. However, the question of whether people think that being a member of the Eurozone has been good or bad for the respondents' country is still asked in the 2014 survey. In 2014, $62 \%$ of the Spaniards thought that being a member of the Eurozone had been "bad" for Spain (only one percentage point less than in the 2013 survey). Transatlantic Trends 2014 , at 29.

2. See Transatlantic Trends: Key Findings 2012, GERMAN MARShaLl Fund OF THE U.S., http:/trends.gmfus.org/files/2012/09/TT-2012-Key-Findings-Report.pdf, at 20 [hereinafter Transatlantic Trends 2012].

3. See, e.g., La Majoría Apuesta por el euro, InsTITUTO DYM (May 2, 2012), http:/www.institutodym.es/ca/actualidad/la-mayoria-apuesta-por-el-euro/ (finding 34\% of Spaniards think that Eurozone exit would be good for Spain) (Most Bets on the Euro). See also José Pablo Ferrándiz, Rescatados, quizá, pero con euros, EL PAIS (May 21, 2012), available at http://blogs.elpais.com/metroscopia/2012/05/rescatados-quiza-pero-con-euros.html (finding 27 $\%$ of Spaniards think that exit would be the best option) (Rescued Perhaps, But With Euros).

4. The debate began after the Spanish media leaked that the Director of the Economic Office of the Spanish Prime Minister, Mr. Alvaro Nadal, was considering strategies for Spain 
to which this story is true. What is clear is that this information prompted public debate on the issue in the country. The result of this debate is the growing tendency of the Spanish people to think that some economic relief could be found outside the Eurozone.

This article is radically agnostic as to the costs and benefits that a decision in that direction would have for Spain and for the Eurozone as a whole. To the best of my knowledge, there is no single serious academic study that computes the economic, social, and political consequences that such a decision would have for both Spain and the European Union, as a whole. My objective is, therefore, not to discern whether Spain would or should leave the euro. The objective is, rather, the more humble one of offering a preliminary discussion about the main economic determinants that a country would have to take into account if it were considering adopting a decision of this kind. Spain is used as a case study, but the conclusions of this article are of a general nature.

To approach the issue of the economic euro-exit determinants, I shall therefore proceed in the following way. A first point is to try to understand when countries have more propensities to leave currency unions. A lookbe it cursory - at the history of currency unions is needed here. A second point also has to do with history, since being more inclined to leave currency unions does not say anything about the positive prospects or negative consequences derived from this event. There are countries that after leaving a currency union (or a similar arrangement) have been very successful, while others have not been successful. It is important thus to understand what made some successful and others not. Furthermore, if there had been no success stories, then the question of whether to leave would be futile. EU Member States would not even contemplate this option had there been no success stories throughout the history of currency union exits.

Finally, it is also important to try to identify what variables make the time ripe for considering a decision of this magnitude. But before we deal

exiting the euro. See e.g., Ignacio Escolar, Un sector del Gobierno Plantea Amenazar a Alemania con Romper el euro, ESCOLAR (2012), http://escolar.net/MT/archives/2012/06/ unsector-del-gobierno-plantea-amenazar-a-alemania-con-romper-el-euro.html (threatening Germany with a Eurozone breakup without financial assistance). The debate was further fired up when three Spanish economists published an article in the Spanish newspaper El País in which they argued that leaving the euro would be equivalent to going back to the "Spain of the 50s." See Jesús Fernández-Villaverde et al., No queremos volver a la España de los 50, EL PAIS (June 1, $2012 \quad 7: 40 \quad$ CET), available at http:/elpais.com/elpais/2012/05/31/opinion/1338475092_453958.html. See also Jesús Rivasés, Un gran negocio llamado España, TIEMPO (June 22, 2012 10:41), available at http://www.tiempodehoy.com/opinion/jesus-rivases/un-gran-negocio-llamado-espana (making reference to Spain's exit from the Euro as one of the alternatives that Rajoy's government contemplated in June 2012). 
with the previous points, it is necessary to account for the causes and consequences of the current economic situation in Spain. I turn to this point in the next section.

\section{Table 1: The Euro, bad or good?}

Generally speaking, do you think that using the euro in [COUNTRY][WITHIN THE EUROZONE: has been / OUTSIDE THE EUROZONE: would be] a good thing or a bath thing for the [COUNTRY] economy?

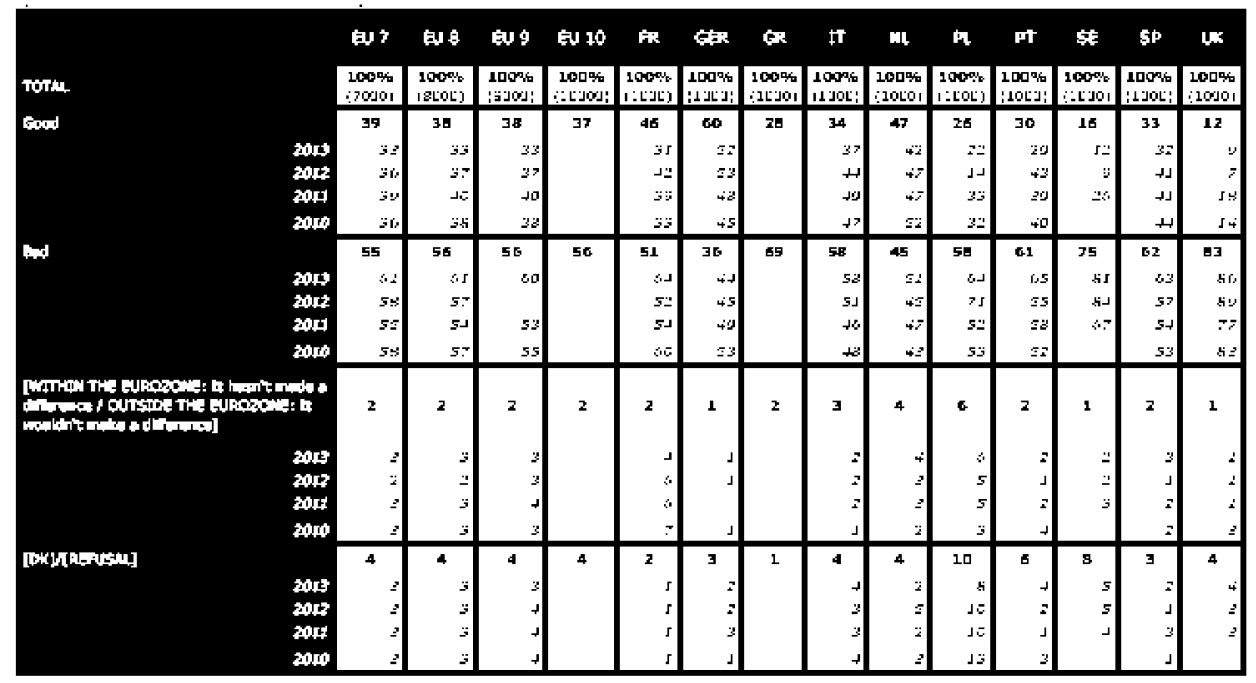

Source: Transatlantic Trends: Topline Data 2014, GERMAN MARSHALL FUND OF THE UNITED STATES (2014), http://trends.gmfus.org/files/2012/09/Trends_2014_ToplineData.pdf, at 66. 
Figure 1: Should I leave or should I stay?

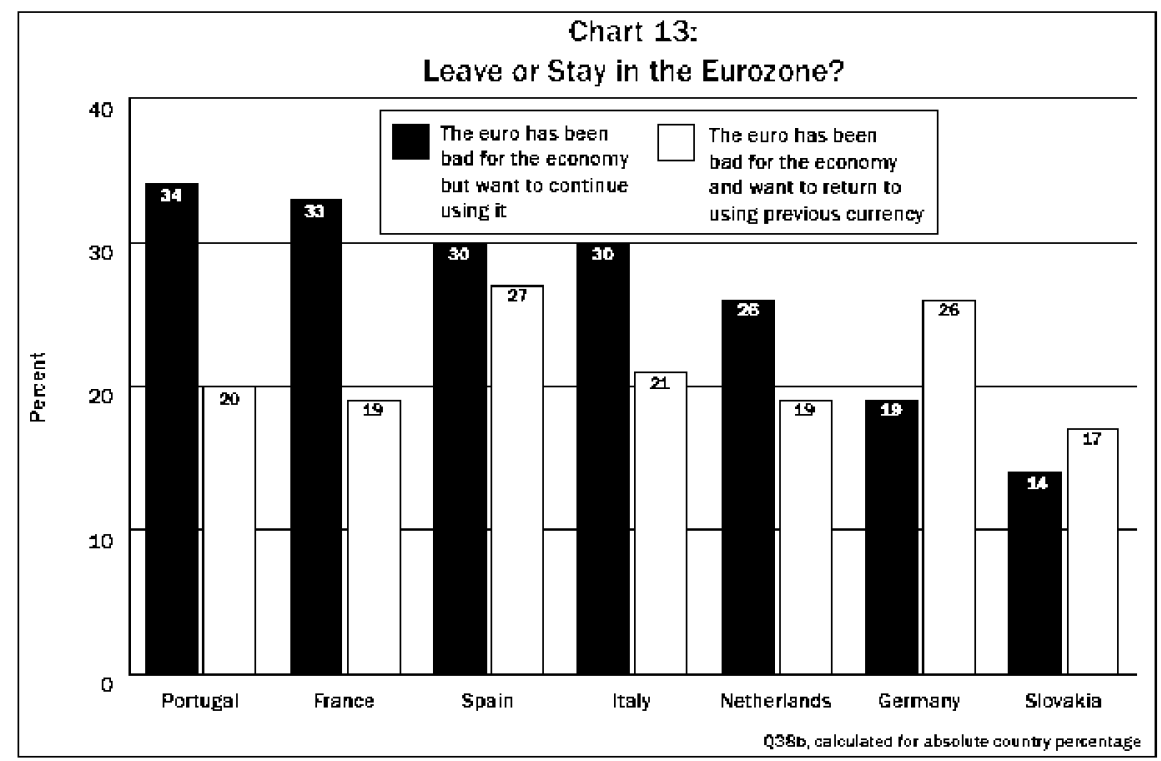

Source: Transatlantic Trends 2012, supra note 2 , at 20.

\section{The CURREnT SPANISH ECONOMIC DOWNTURN}

\section{A. The European Variable}

To better grasp the causes of why Spain is experiencing the current economic situation, it is necessary to take into account three important EU institutional features. The first two are contingent, the third is more structural. The two contingent features have to do, first, with the powers of the European Central Bank (ECB), and second, with the no-bailout clause. The third is, as I said, more structural. It has to do with the EU decision-making process.

I will not expand on any of these features, since they are all well known. The European Central Bank's (ECB) powers are basically limited to the control of prices. ${ }^{5}$ It is true that the ECB must also be concerned

5. See Consolidated Version of the Treaty on the Functioning of the European Union arts. 127, 140, 282, Oct. 26, 2012, 2012 O.J. (C 326) 47 [hereinafter TFEU]; Protocol (No 4): On the Statute of the European System of Central Banks and of the European Central Bank, Sept. 26, 2012, 2012 O.J. (C 32) 230; Protocol (No 13): On the Convergence Criteria, Sept. 26, 2012, 2012 O.J. (C 326) 281. 
with the "general economic policies in the Union."6 But even if we afforded this a generous reading, as the ECB has probably done recently, there is consensus in the sense that the ECB lacks powers to prompt economic growth and fight against unemployment-tasks that the Federal Reserve unquestionably has in the United States. ${ }^{7}$ As things were going well, as they basically did until 2007-2008, the debate about the exact contours of the ECB powers remained an academic one. However, in the midst of the crisis, discussion about the ECB's statute has spread and even reached the public square. ${ }^{8}$ This is indicative of a growing public discomfort with the role that the $\mathrm{ECB}$ is playing in EU monetary governance. 9 To be sure, uneasiness with the ECB's performance is higher in southern European countries than in northern ones. ${ }^{10}$ Therefore, the debate on the proper role for the ECB, among other things, further illustrates the growing cleavage that exists between the north and the south of the European Union. ${ }^{11}$

6. See TFEU, supra note 5, at art. 127(1) ("The primary objective of the European System of Central Banks (hereinafter referred to as 'the ESCB') shall be to maintain price stability. Without prejudice to the objective of price stability, the ESCB shall support the general economic policies in the Union with a view to contributing to the achievement of the objectives of the Union as laid down in Article 3 of the Treaty on European

Union. The ESCB shall act in accordance with the principle of an open market economy with free competition, favoring an efficient allocation of resources, and in compliance with the principles set out in Article 119").

7. See 12 U.S.C. \$ 225(a) (Section $2 A$ of the Federal Reserve Act) ("The Board of Governors of the Federal Reserve System and the Federal Open Market Committee shall maintain long run growth of the monetary and credit aggregates commensurate with the economy's long run potential to increase production, so as to promote effectively the goals of maximum employment, stable prices, and moderate long-term interest rates." (emphasis added)).

8. It is interesting to note that when the Euro started circulating as physical currency in 2002, 74\% of Spaniards said that they "had heard about the ECB," whereas 23\% had not. Eurobarometer: Public Opinion in the European Union, Report 58, EUROPEAN COMMISSION (2003), at B.115 [hereinafter Eurobarometer 58]. In 2014, 92\% of Spaniards had heard of it, whereas 7\% had not. Standard Eurobarometer 81: Tables of Results, EUROPEAN COMMISSION (2014), at T55 [hereinafter Eurobarometer 81], available at http://ec.europa.eu/public_opinion/archives/eb/eb81/eb81_anx_en.pdf.

9. Again, for example in $2002,52 \%$ of Spaniards trusted the ECB, whereas $21 \%$ did not, and in $2014,14 \%$ trusted the ECB and $77 \%$ did not. Eurobarometer 58 , supra note 8 at B. 117 ; Eurobarometer 81, supra note 8, at 92 .

10. For example, in Germany, in $2014,38 \%$ of Germans said the trusted the ECB, whereas $4 \%$ did not. Eurobarometer 81, supra note 8, at 92.

11. According to the Marshall Fund, the "[n]orth-[s]outh [d]ivide [w]idens in Europe." Transatlantic Trends 2014, supra note 1, at 30 . This survey finds a correlation between people's sentiment on how the crisis is affecting them and the extent to which they blame the EU. Therefore, the more they feel they are affected by the crisis, the more they blame the EU. For example, in Germany, 30\% of the respondents said that they felt personally affected by the crisis, whereas in Spain $81 \%$ felt they were personally affected by the crisis. Id. In turn, in Germany $60 \%$ said that the EU was not doing enough to combat the crisis, whereas in Spain $88 \%$ thought that the EU was not doing enough to fight against the crisis. $I d$. 
The second feature of EU economic governance that I mentioned before was the no-bailout clause. According to this clause, if a Member State faces economic difficulties, and it cannot pay its debts, then there is neither an obligation from the rest of the Member States nor from the European Union as a whole to help it. The idea behind this was that Member States should understand that there would be no safety net from the European Union (or from the rest of the Member States) in case they should run amok. ${ }^{12}$

The no-bailout clause was complemented with a number of provisions regarding the proper functioning of the euro. In particular, the Functioning Treaty gave powers to the EU institutions to reinforce its stakes, vis-à-vis Member States doing the wrong thing. ${ }^{13}$ This formed the "constitutional" basis of the Stability and Growth Pact (SGP): a number of measures (both preventive and reactive) that the EU institutions might adopt in the case in which a Member State overshot its public deficit and debt limits as established by the EU Treaties. The idea behind the SGP was that the bad members of the European Monetary Union should be castigated for it, and no provision was established in order to "help" Member States in difficulties. If anything, Article 136 of the Functioning

12. See TFEU, supra note 5 , at art. 125 (1). This article is duly supplemented by TFEU art. 123. Id. at art. 123. The latter article establishes two rules: firstly, that the ECB cannot bail out member states, and therefore cannot act as a lender of last resort for this purpose; and secondly, that the ECB can only buy sovereign debt in secondary markets and not directly from the member states. Randall Henning and Martin Kessler argue that the EU no bailout clause finds inspiration in the US tradition on this issue. These authors reconstruct the historical process through which the United States of America introduced the no-bailout clause in the 19 th century. These laws were enacted in the $1840 \mathrm{~s}$, after nine American states had defaulted. See R. Daniel Kelemen \& Terence K. Teo, Law, Focal Points, and Fiscal Discipline in the United States and the European Union, 108 AM. POL. SCI. REV. 355, 355 n. 1 (2014). The main reason for this is that at that time, fiscal federal powers were already important enough to ensure that other federal programs could compensate for the prohibition of bailouts. According to the authors, "the US experience suggests that the particular path through which rules are adopted and enforced is likely to be critical to their implementation and that introducing such rules for euro area member states should be accompanied by a federal system of fiscal powers and a common fund for rescuing and recapitalizing banks." C. Randall Henning \& Martin Kessler, Fiscal Federalism: US History for Architects of Europe's Fiscal Union 18 (Peterson Inst. for Int'l Econ., Working Paper No. 12-1, 2012). In other words, one cannot have one (a no-bailout clause) without the other (strong fiscal federal or central powers). See id. To have the first without the second is therefore to have the worst of both worlds.

13. See TFEU, supra note 5, at art. 126; See also Consolidated Version of the Treaty on European Union, Protocol No. 12 On the Excessive Deficit Procedure, Sept. 5, 2008, 2012 O.J. (C 326) 1. 
Treaty seemed to open up the door for measures different from sanctions, although it did so in a rather ambiguous and diffuse manner. ${ }^{14}$

It is important to recall at this point that those Member States that had fought hard to obtain a stringent SGP, (e.g., France and Germany), were the ones that disruptively forced its reform in order to give it more flexibility from 2003 onward, something that they achieved with the first reform of the SGP in 2005. This story is well known and does not have to be repeated here in detail. ${ }^{15}$ Suffice to say that in 2003 these two countries ran public deficits and debts that went beyond their respective limits as set by the SGP. Both Member States united to provoke its reform. However, this was not a story of victims on the one hand and villains on the other. The roles of victims and villains were mixed: France and Germany had the support of other countries, specifically of the countries that could be doing worse under a more stringent SGP. ${ }^{16}$ These Member States saw in this an opportunity to advance their own particular interests. But this is probably not the point. After all, one cannot blame the worse off for being rational and therefore jumping onto the bandwagon of modulating the SGP's old rigors. The point is, rather, that it created a pervasive impression that the EU economic governance rules, and above all, its monetary rules, were hand-tailored for the principal beneficiaries of the monetary union. This, it is submitted, had profound consequences for the way in which, later on, markets viewed the capacity of the European Union to solve the current economic crisis. ${ }^{17}$

14. See TFEU, supra note 5, at art. 136. In fact, Article 136 of the TFEU has been amended by European Council Decision of 25 March 2011 in order to introduce a third paragraph. See Council Decision 2011/199/EU, 2011 O.J. (L 91) 1. The third paragraph establishes the possibility to create a European Stability Mechanism. This amendment entered into force on May 1, 2013, after the EU Council's Secretary General received notification by the Czech authorities of the completion of the ratification procedure in this member state. Directorate General for the Presidency \& Directorate for Relations with National Parliaments Legislative Dialogue Unit, Table On the Ratification Process of Amendment of art. 136 TFEU, ESM Treaty and Fiscal Compact, EUROPEAN PARLIAMENT, (Sept. 27, 2013), http:/www.europarl.europa.eu/webnp/cms/pid/1833.

15. See generally Ludger Schuknecht, Et al., European Central Bank, The Stability AND Growth PACT. CRISIS AND REFORM, 129 OCCASIONAL PAPER SERIES 10 (2011) (providing a summary on how France and Germany fought to achieve reform of the SGP in 2005).

16. Spain, in particular, supported French and German attempts to reform the SGP. See Cristina Serrano and Begoña Montoro Zulueta, El Pacto de Estabilidad y Crecimiento [Stability and Growth Pact], 2905 BOLETÍN ECONÓMICO DE ICE 3, 7 (2007). According to the authors, "Spain adopted a flexible stance throughout the re-negotiation of the SGP, showing particular sensitivity and understanding towards France and Germany's problems." (author's translation).

17. An impression probably not mitigated by the fact that the SGP was reformed again in 2011. Also under French and above all German pressure, this time the aim was to reintroduce more discipline and rigor to European monetary governance. See SCHUKNECHT ET AL., supra note 15 , at 18 . 
The last element that closes this institutional triangle is the EU decision-making process. As previously stated, this element is more structural, whereas the other two elements are more contingent. With this I mean that though, at least in theory, it would be conceivable to have an ECB with enlarged powers, and also a different EU economic and above all monetary governance setting, it is instead very hard to imagine how the EU decision-making process could be made less cumbersome and complex. It is not only that size matters here (at the time of this writing, the European Union contains twenty-eight Member States and is still growing). It is also that real convergence among Member States (political, economic, and social) is far from evident. ${ }^{18}$ Therefore, complex decision making is likely an idiosyncratic feature of the European Union, such as it is now. It is also probable that the complexity of the EU decision-making process negatively impacts the reform prospects of the other two elements mentioned above. Stated in different words, if one had to establish a sort of hierarchy in regard to the three explanatory variables we are commenting on, the EU's complex and cumbersome decision-making process would preside over the other two.

The fact of the matter is that it takes a lot of time for the Union to make decisions, and this is increasingly evident. ${ }^{19}$ This delay occurs ordinarily, but it is the case in extraordinary circumstances as well. Decision-making lags are problematic under the first; they are utterly fatal under the second. It makes it simply impossible to quickly react to the changes brought about by very volatile contexts, such as the current one. The example of the timespan that elapsed since the European Union first started to talk about establishing a Permanent Stability Mechanism (the European Stability Mechanism, or ESM) to help Member States with difficulties, until it definitively adopted one, is very illustrative of this trend.

As we have said before, the no-bailout clause was the first obstacle. Therefore, the EU Treaties needed to be amended to establish an assistance mechanism. Member States had to negotiate such a modification. Then Member States had to bargain about the exact contours of the new financial vehicle. The third step was to make a

18. See generally Antonio Estella, European Union Scenarios for 2017, 1-29 (Royal Instituto Elcano, Working Paper 39, 2008) (assessing several outcomes for the EU in 2017 based on current trends).

19. According to Thomas König, the EU decision-making process has on average slowed down in recent years. While the median proposal time lag was about 100 days until the end of the $1980 \mathrm{~s}$, it increased in the early $1990 \mathrm{~s}$ to 140 days. In general, König gives flesh to an intuitive argument: as the EU augments divergence through enlargement to new member states with different interests, the decision-making process slows down. See Thomas König, Divergence or Convergence? From Ever-Growing to Ever-Slowing European Legislative Decision Making, 46 EUR. J. POL. RES. 417, 419 (2007). 
decision about the best way to fund the new mechanism. Further, the ESM had to enter into force. The total time that elapsed since the beginning of this operation was two years, and this is taking into account that the ESM is not part of the European Union law framework. ${ }^{20}$ The lourdeur of the EU decision-making process, its difficulty to make decisions even under pressing extraordinary circumstances, has even been echoed in the political sphere: for instance, Spanish Prime Minister Mariano Rajoy has repeated on different occasions that the EU is "desperately slow."21

\section{B. The National Perspective}

It is against this institutional context that one has to project the events that unfolded after the bursting of the subprime crisis and the subsequent collapse of Lehman Brothers in September 2008. As the general story is already known, ${ }^{22} \mathrm{I}$ will only refer to the Spanish specifics. ${ }^{23}$ It is by now very clear that the euro helped to create a credit bubble in Spain. This credit bubble was mainly channeled to the housing market in this country. Fishman attributes this precisely to the lack of a powerful and dynamic industrial sector in the vast majority of the

20. First high-level conversations about the issue can be traced back to the Deauville Summit (October 2010) that was held between Russia, Germany and France. At this summit, Angela Merkel and Nicolas Sarkozy issued a joint statement in which they called the EU to draw proposals to establish a Permanent Financial Assistance Mechanism. See FranceGermany-Russia Summit, Oct. 18, 2010, Franco-German Declaration; See also EU Agrees to Merkel's Controversial Euro Reforms, SPIEGEL ONLINE (Oct. 29, 2010, 1:26 PM), http://www.spiegel.de/international/europe/brussels-summit-eu-agrees-to-merkel-scontroversial-euro-reforms-a-726103.html. The European Stability Mechanism (ESM) was later on established as a Public International Law Treaty. This Treaty entered into force on September 27, 2012 (except for Estonia, for which it entered into force on October 4, 2012). The Mechanism was inaugurated on October 8, 2012. See generally EuropeAN STABILITY MECHANISM, http:/www.esm.europa.eu/index.htm (last visited Apr. 4, 2015).

21. Fernando Garea, Rajoy: "La UE se Mueve, Aunque a un Ritmo Desesperadamente Lento" [the EU Moves, Even if at a Desperately Slow Pace], EL PAÍs (Oct. 31, 2012, 6:32 PM), http:/politica.elpais.com/politica/2012/10/31/actualidad/1351673513_108674.html.

22. See generally PAUL KRUGMan, End This DePREssion Now! (2012) (reviewing the fiscal crisis of 2007); CARMEN M. REINHART \& KENNETH S. ROGOFF, THIS TIME IS DIFFERENT: EIGHT Centuries of FinANCIAL FolLy 199-222 (2009) (exploring general economic trends over time, and noting their repetitive nature); JosEPH E. STIGLITZ, FrEEFALL: AMERICA, FreE MARKETS, AND THE SINKING OF THE WORLD ECONOMY (2010) (assessing in particular how the failure of U.S. financial markets had disastrous consequences on the global economy).

23. See generally Eloísa Ortega \& Juan Peñalosa, The Spanish Economic Crisis: Key Factors and Growth Challenges in the Euro Area, BANCO DE ESPAÑA: DOCUMENTOS OCASIONALES, no. 1201, 2012 (examining the fiscal crisis in Spain, and determining if lack of adaptability to the macro-economy of EMU membership was and continues to be a factor). 
country. ${ }^{24}$ Therefore, the credit bubble prompted a real estate bubble. Money being cheap, virtually everyone had access to real estate ownership. However, as this was happening, a mirroring process of increasing prices came about. Real estate prices were increasingly high, but people could afford them due to the substantial capital inflows that were coming to Spain, specifically, from northern EU countries. Both bubbles were reinforcing each other. The more the credit bubble grew, the more the real estate bubble grew. In turn, as the real estate bubble grew, there was an increasing demand for cheap money. The result was an impressive increase in real exchange rates and therefore a loss in the competitiveness of the Spanish economy. ${ }^{25}$

This is not to suggest that this process was automatic. It was simply rational for economic actors to want to access real estate in general and housing in particular since money was cheap and housing rental prices were high. It was also rational for Spanish creditors to keep pumping money into the Spanish economy since there was a demand for it, and, as the real estate market was expanding, the solvency of debtors was never put into question. If the subprime crisis and in particular Lehman Brothers collapse had not happened, it is very probable that Spain would not be in such a harsh economic situation today. But Lehman did collapse and, overnight, capital inflows to Spain started decreasing. Therefore, credit was less available than before in Spain, and, in a question of months, it almost came to a halt. With no credit, the real estate and housing markets bubbles burst.

Spanish economic operators, and above all real estate market agents, turned their eyes to the Spanish government. The Spanish government came to the rescue. The first step was a typical, neo-Keynesian, reaction. If, due to the lack of credit, the housing demand had stopped, then it should be stirred again. Therefore, Spain spent around 100 billion euros in just a couple of years in trying to reactivate the housing and public works sectors again. ${ }^{26}$

It worked for a while, and the hope was that the crisis would not be as profound as was proven afterward. Spain had accumulated a budgetary surplus during the previous years; the government used it, but the crisis

24. The exception being the Basque country, where the coordinated efforts of industry and policy makers made it possible to channel credit to small and medium enterprises, rather than to the housing and real estate sectors. See Robert M. Fishman, Anomalies of Spain's Economy and Economic Policy Making, 31 CONTRIBUTIONS TO POL. ECON. 67, 71 (2012).

25. See José Fernández-Albertos, Democracta Intervenida: Políticas Económicas en la Gran ReCesión [INTERVEned DeMOCRACY: ECONOMiC POLICY in the Great RECESSION] 51 (2012).

26. Spain implemented the "Plan para el Estímulo de la Economía y el Empleo" (Stimulus Plan for the Economy and Employment), popularly known as Plan "E," from November 2008 until 2010 . 
worsened and the surplus was over. Spain started running up public deficits. The downward trend was more worrisome than the actual numbers. In 2009, Spain had not only spent its surplus but also overshot the public deficit and debt limits established by the Stability and Growth Pact.

It is at this point that our three institutional elements, previously mentioned, enter the scene. In the same way that economic operators had turned their eyes to the Spanish government, now it was the Spanish government's turn to ask the European Union institutions for assistance. But the answer from Europe was three-fold. First, the ECB was there to keep inflation rates under control-not to rescue states that had run amok. Second, there was no financial assistance mechanism with enough firepower to contain Spanish hemorrhaging. Third, decisions could be taken, but this would need the support of most if not all Member States and therefore would take time. In other words, Spain had suddenly discovered that it was trapped in the $\mathrm{EU}$ institutional triangle that $\mathrm{I}$ described above.

Financial markets soon realized that Spain was trapped in the institutional triangle just described and that an exit from it would be very hard to find. Without the help of the European Union-and in particular of the ECB, which was reluctant to monetize the Spanish debt-markets were less willing to lend money to the country. Spreads between Spanish bonds and German bonds started skyrocketing. ${ }^{27}$ The situation got more complicated when markets, probably to their delight, observed that as cumbersome as it might be, the main answer from Europe was in the form of austerity. What initially was a liquidity problem turned into a real solvency one, since the outcome of austerity was stagnation (when not economic deflation) (see Figure 2, infra p. 347) and high unemployment (see Figure 3, infra p. 348). The end of this story is well known: once the

27. Spanish risk premium started its escalating trend on April 14, 2010. A month later, on May 7, 2010, the Spanish risk premium was at 162 basis points. The government took the first budget cuts a few days later, on May 12, 2010, and the Spanish risk premium decreased to 103 basis points. However, the success of these measures was short-lived: only a month later, on June 17, 2010, the Spanish risk premium was at 216 basis points. The Spanish spread with German bonds reached its historically highest point on July 24, 2012 (637 basis points). Days later, on July 26, 2012, Mario Draghi made a statement saying that the ECB was ready to do "whatever it takes" to save the euro. Mario Draghi, Verbatim of the Remarks Made By Mario Draghi: Speech by Mario Draghi, President of the European Central Bank at the Global investment Conference in London, EUR. CENT. BANK (July 26, 2012), http:/www.ecb.int/press/key/date/2012/html/sp120726.en.html. After that statement, the spread between Spanish 10-year bonds and German ones decreased to 351 basis points by January 18, 2013. At the time of this writing (October 2014), the Spanish risk premium is at around 150 basis points (therefore, not very far away from the level in which it was days before the first budget cuts were adopted in May 2010). For the evolution of Spanish risk premium, see infra Figure 15. 
ESM was activated, Spain had to ask for a bailout for its banking sector, to which the ESM adjoined stringent conditionality. The first tranche of the bailout was disbursed in December 2012 and the second in February 2013. Spain formally exited the bailout program in December 31, 2013, but, at the time of this writing, the chances that it will have to recur to the ESM again in the future have not completely faded away.

Figure 2: Spain's GDP growth as annual percentage 2006-2013

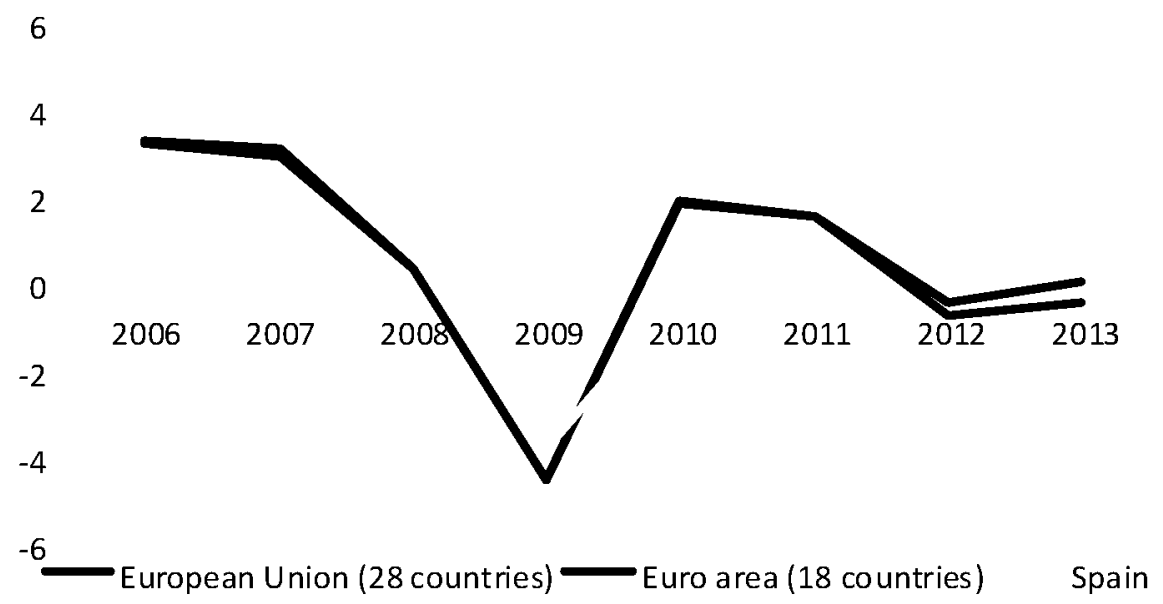

Source: GDP and Main Components - Volumes, Eurostat, http:/appsso.eurostat.ec. europa.eu/nui/show.do?dataset=nama_gdp_k (last updated Dec. 8, 2014). 


\section{Figure 3: Spain's unemployment rate as a percentage of labor force 2013}

\section{3}

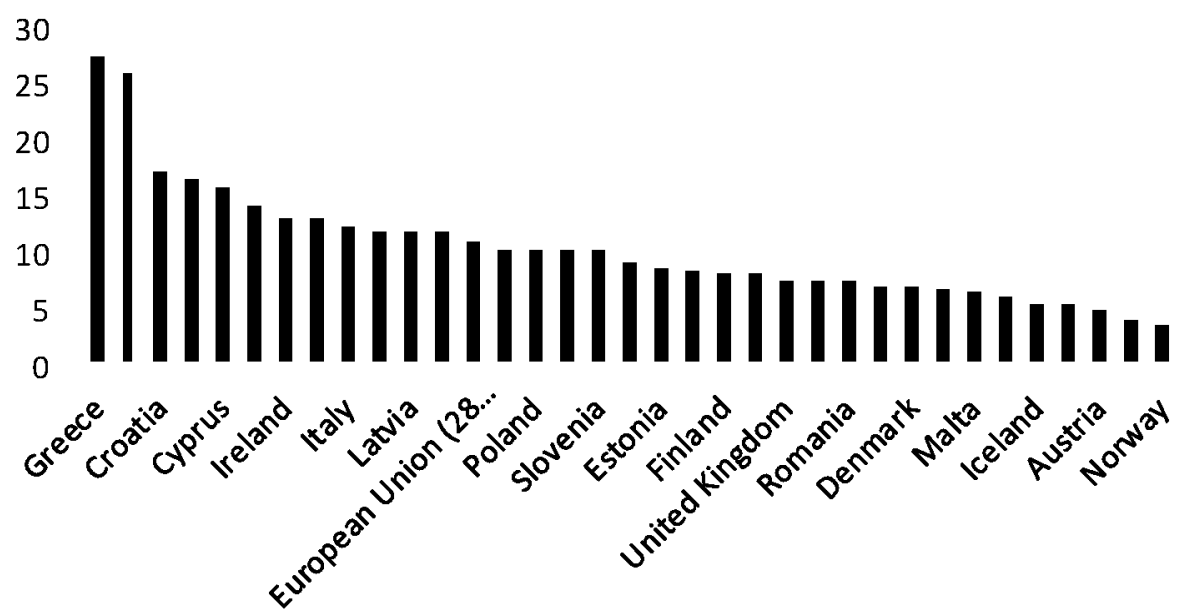

Source: Unemployment Rate - Annual Data, EUROSTAT, http://ec.europa.eu/eurostat/tgm/ table.do?tab=table\&init=1\&language=en\&pcode=tipsun20\&plugin=1 (choose the "Graph" tab; then choose the "Data" tab, select "2013" and click "Refresh"; then choose the "Sort and label" tab, select "Descending," and click "Refresh") (last visited Mar. 27, 2015).

\section{THE EXITER's PROFILE}

We may now turn to the analysis of the economic determinants of euro-exit. In a path-breaking study on currency unions, Andrew K. Rose analyzes exit from currency unions after the Second World War. ${ }^{28} \mathrm{He}$ compares sixty-nine cases of exit, in which countries have left currency unions, with sixty-one cases in which countries belonging to currency unions did not leave. From these cases, Rose establishes what could be called an "exiter's profile." 29 His findings are therefore relevant to our discussion. ${ }^{30}$ According to the author, "exiters tend to be larger, richer, and

28. See Andrew K. Rose, Checking Out: Exits from Currency Unions, 19 J. FIN. TRANSFORMATION 121, 128 (2007).

29. That is to say, the characteristics of countries that have more propensity to leave currency unions.

30. Roger Bootle points out the following as regards Rose's analysis: "the countries included in [Rose's] study have little in common with the euro-zone" since "they are mostly small, post-colonial economies which used the currency of a larger neighbour or a colonial power. Many used currency boards which continued to issue their own currency but pegged it 
more democratic than stayers."31 However, Rose also warns against overshooting these differences, since they tend to be "persistent" but "sluggish."32 In my opinion, this warning should be understood in the sense that it is important to be very specific and detailed about the mechanisms that are at play in this domain. Rose's findings are the following:

When one considers all the variables simultaneously, only five show through with sizable effects. The size and income of the country are both strongly positively associated with monetary independence, consistent with Alesina and Barro (2002). More democratic countries and those with larger government sectors are systematically more likely to have their own currencies. Finally, inflation is higher with currency union exiters than stayers, though the causality here is ambiguous. High inflation countries may find it more difficult to remain with currency unions, as their competitiveness cannot be regained through a nominal devaluation; but countries with their own money may simply have systematically less disciplined monetary institutions and accordingly higher inflation. More democratic countries and those with larger government sectors may find it easier to respond to asymmetric macroeconomic shocks, but are less likely to remain in currency unions. ${ }^{33}$

Rose's article relates the three main conditions that he finds to be the best predictors of exit (e.g., size, wealth, and democracy) with the following measures. First, size and wealth are understood in terms of population,

firmly to an "anchor" currency. What's more, few if any of these countries had large external or public debts and few, if any, had uncompetitive currencies. But it is these issues of debt and competitiveness which are the key problems faced by the euro-zone." Roger Bootle et. al, Leaving the Euro: A Practical Guide, WOLFSON ECONOMICS PRIZE 2012, at 18, http:/www.policyexchange.org.uk/images/WolfsonPrize/wolfson $\% 20$

economics\%20prize\%20winning\%20entry.pdf (last visited Mar. 27, 2015). However, as the same authors recognize later on in the same study, the problem is that there is no case in history similar to the one of the Eurozone. See id. at 72. There are cases in which a whole monetary union collapsed, but there are no cases in which one of the members of a monetary zone left. See id. at 18-19, 72-73. Even if probably incomplete, Rose's analysis is therefore a good point of departure to answer the question of which states have a greater tendency to leave currency unions

31. See Rose, supra note 28 , at 122 .

32. See id. at 122 .

33. See id. at 127. 
real GDP per capita, openness (exports plus imports), direct government spending, and investment. Other measures that he includes are inflation, budget balance, money growth, and the national accounts. Rose uses a number of different sources for calculating these measures. ${ }^{34}$ However, he uses the Penn World Tables as a default source of information, which he complements with the others when some specific information is missing. Clearly, some of these measures are more related to size, some others are more related to richness, and others again are arguably related to both. For example, population and GDP per capita are related to size and wealth, respectively. Government spending may be related to both size and richness. In turn, openness and investment may be also related to both. In any event, I will proceed in the same way Rose does to understand the position of Spain in terms of size and wealth but, for the sake of simplifying my analysis, will use only some of the measures he finds of relevance to account for each of these variables. Therefore, I will use population as a proxy of size, government spending as a proxy of size and wealth, and GDP per capita (PPP) as a proxy of wealth. I also include GDP (PPP) - which Rose does not include - to give a further measure of both size and wealth. However, I exclude inflation and trade (openness), since according to Rose, none of them are clear determinants of exit. ${ }^{35}$ Further, instead of using the World Penn Tables (since data for some variables is not updated to recent years), I use the CIA World Factbook (which offers much more up-to-date information).

In regard to democracy, Rose uses the Polity series of the University of Maryland's Center for International Development and Conflict. The Polity Series codifies countries according to a number of characteristics of governing institutions. This allows Polity to offer an index of 167 countries. In this index (see Figure 4, infra p. 352), countries are codified as "full democracies," "democracies," "open anocracies," "closed anocracies," "autocracies," or "failed/occupied." Furthermore, within each of these categories, countries are given a specific score, which allows for comparison within each group and also to account for changes in single countries. For example, the lowest score that countries belonging to the second category (democracies) can obtain is +6 , and the highest is +9 . However, only full democracies get a single score: +10 .

34. See id. at 123-24 (stating that Rose uses the "Penn World Tables (version 6.2)," the "World Bank's World Development Indicators," and the "International Monetary Fund's International Financial Statistics" for calculating the listed measure).

35. See id. at 127 ("I]nflation is higher for currency union exiters than stayers, though the causality here is ambiguous," and there is an "absence of any strong tie between the importance of trade and currency union membership."). 
Table 2: Spain's position in the world: Population, GDP, Government Budget, GDP per capita and Democracy

\begin{tabular}{|l|l|}
\hline Variables & Spain's Position in Ranking \\
\hline Population & $29(2014)$ \\
\hline GDP (PPP) & $15(2013)$ \\
\hline GDP per capita (PPP) & $47(2013)$ \\
\hline Budget Size (revenues) & $10(2013)$ \\
\hline Democracy & Highest (2013) \\
\hline
\end{tabular}

Sources: Central InTelligenCE AGenCy, THE WORLd FACtBoOK (51st ed. 2014), available at https://www.cia.gov/library/publications/the-world-factbook/ (multiple pages); POLITY IV, http:/www.systemicpeace.org/polity/polity4x.htm (last updated June 5, 2014).

Data for all variables on Spain are summarized in Table 2. Starting with the latter aspect (democracy), and irrespective of the criticisms that the Polity Score has received ${ }^{36}$ (the Index can be more useful to measure transitions between different political regimes than evolution within fully institutionalized democracies), Spain is placed in the group of States that are labelled as "full democracies," and therefore it obtains the highest score $(+10$ ) (see Figure 4, infra p. 352).

36. See generally Gerardo L. Munck \& Jay Verkuilen, Conceptualizing and Measuring Democracy: Evaluating Alternative Indices, 35 COMP. POL. STUD. (2002) (evaluating the weaknesses of democracy indices). 
Figure 4: Polity IV, Individual Country Regime Trends, 1946-2013 Source: POLITY IV, http://www.systemicpeace.org/polity/polity4x.htm (last

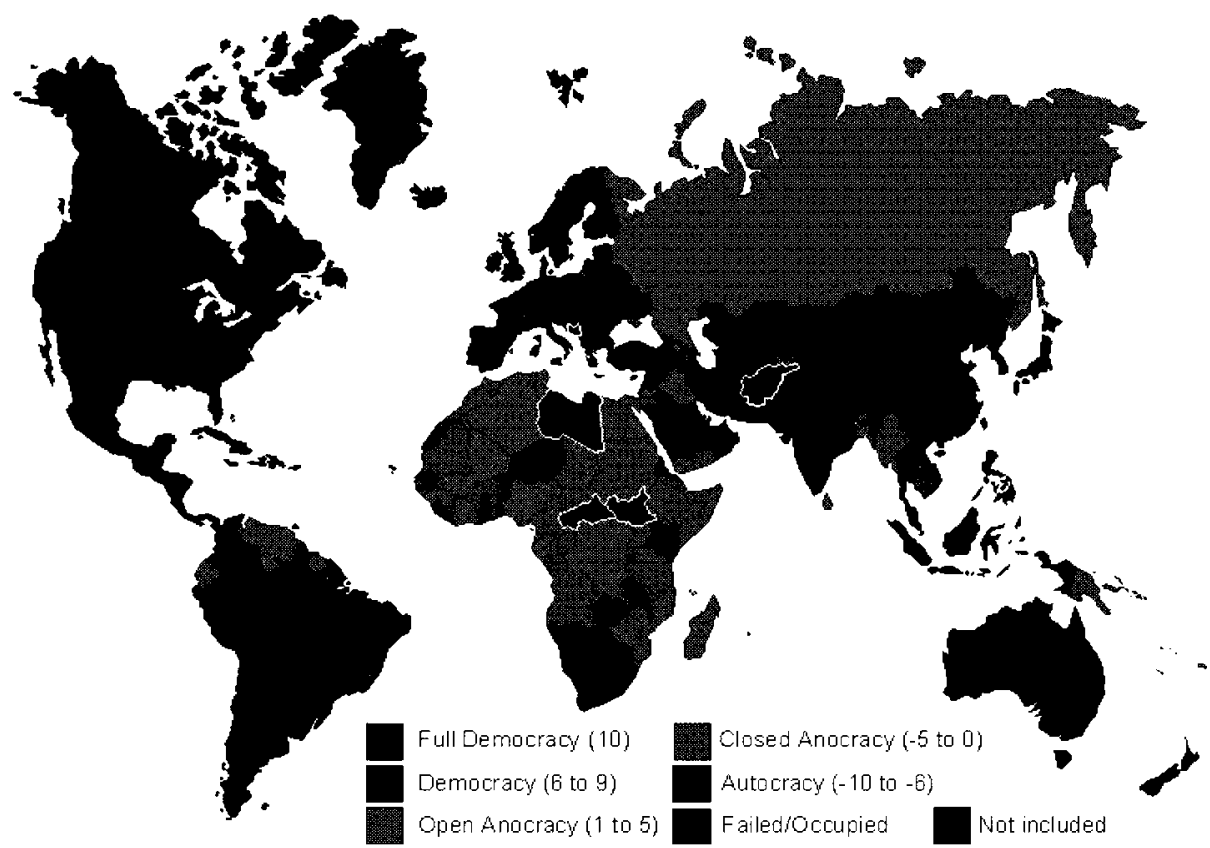

updated June 5, 2014).

Furthermore, with regard to size, if measured by population, Spain occupies position twenty-nine (out of 240 countries that appear in this index) ${ }^{37}$ If measured by GDP, Spain's place in the world is number fifteen (229 countries). ${ }^{38}$ Finally, in terms of the size of the government budget (measured as revenues), Spain occupies position number fifty-six, out of 233 countries surveyed ${ }^{39}$

However, regarding GDP per capita (a measure of a country's wealth), Spain occupies position number forty-seven in the world (out of 228

37. Central Intelligence Agency, Country Comparison Population, in THE WORLD FACTBOOK, (51st ed. 2014), available at https:/www.cia.gov/library/publications/the-worldfactbook/rankorder/2119rank.html.

38. Central Intelligence Agency, Country Comparison GDP (Purchasing Power Parity), in THE WORLD FACTBOOK (51st ed. 2014), available at https:/www.cia.gov/library/ publications/the-world-factbook/rankorder/2001rank.html.

39. See Central Intelligence Agency, Field Listing: Budget, in THE WORLD FACTBOOK (51st ed. 2014), available at https://www.cia.gov/library/publications/the-world-factbook/ fields/2056.html. 
countries that are included in this ranking). ${ }^{40}$ The severe Spanish economic downturn that started in 2007 explains (in part at least) the position that Spain occupies today. ${ }^{41}$ However, even with these figures in mind, it is still possible to argue that Spain belongs to the medium-to-high countries in the world in terms of wealth. ${ }^{42}$

In conclusion, this data gives a preliminary indication that in terms of Population, GDP, Budget Size (which are proxies for both size and richness), and Democracy, Spain would probably belong to those countries that are more susceptible to leaving currency unions. In terms of wealth (if measured as GDP per capita) the analysis, however, is less conclusive. Nonetheless, it is also possible to think that if the effect of the crisis could be controlled for, then Spain would probably be placed as regards this variable in a better position to leave currency unions, as other rankings seem to indicate.

\section{COUNTRIES' OUTCOMES AFTER LEAVING CURRENCY AREAS OR DEVALUATING: ARGENTINA AND SOUTH KOREA COMPARED}

As we have seen in the previous section, countries that in the past have left currency unions have certain characteristics. I also showed that Spain fits that profile, given the qualifications that have been mentioned therein. However, the previous analysis does not tell us anything - as it is not its main purpose-about whether those countries that left currency unions were successful or not, and if so, to what extent. I undertake that analysis in this section.

The problem of comparing the situation in which Spain, or another member of the Eurozone, finds itself with other historical cases is that it is quite unprecedented. As I have already mentioned, there is no similar case in history. This is the point that Bootle et al. make. ${ }^{43}$ According to these authors, the major historical cases of currency breakups are the AustroHungarian Empire after 1918, the rubble zone after the USSR was dissolved in 1991, and the Czech-Slovak monetary union of 1993. It would also be possible to add other cases to the list. For example, the collapse of

40. Central Intelligence Agency, Country Comparison: GDP-Per Capita (PPP), in THE WORLD FACTBOOK (51st ed. 2014), available at https:/www.cia.gov/library/publications/ theworld-factbook/rankorder/2004rank.html.

41. Spain's position in this ranking may also be due to methodological issues. For example, France is in position number 39, the EU in position number 41, and the UK is in position number 34 . Id.

42. See, e.g., Tina Aridas \& Valentina Pasquali, The World's Richest and Poorest Countries, GLOBAL FINANCE (June 14, 2013), http://www.gfmag.com/tools/global-database/ economic-data/11934-richest-poorest-countries.html\#axzz2BeSQFnC5 (ranking Spain in position number 31 out of 184 countries surveyed and ranked from richest to poorest).

43. See Rose, supra note 28. 
the Latin monetary union or the breakup of the Scandinavian currency union. ${ }^{44}$ However, Bootle et al. also indicate that we are speaking here of cases in which the breakups occurred for political rather than for economic reasons. Furthermore, it could be added that they were also cases in which the economic conditions were very different from those today, in which international financial markets have experienced an unprecedented expansion. ${ }^{45}$ A final aspect would be to point out that in all of these cases, we are speaking of the whole currency union breakup and not of cases in which one of the members of those currency unions left. Bootle et al. sensibly recommend focusing on more recent cases, in which the countries in question had high levels of external debt (be it public, private, or both). They also recommend focusing not on currency breakups (very rare in history as I have said) but rather on cases in which the countries in question largely devalued their currency and partially defaulted. These authors focus, in particular, on the following cases: Argentina in 20012002, Russia in 1998, and East Asia in 1997. There is no single account, to my knowledge, that analyzes and compares all historical cases in which countries have devalued and defaulted. ${ }^{46}$

44. See generally Kee-Hong Bae \& Warren Bailey, The Latin Monetary Union: Some Evidence on Europe's Failed Common Currency, 1 REv. Dev. FIN. (2011) (examining the financial and economic record of the Latin Monetary Union); Lars Fredrik Oksendal, The Impact of the Scandinavian Monetary Union on Financial Market Integration, 14 FIN. HisT. REV. (2007) (examining the significance of the Scandinavian Monetary Union). It has to be noted that the main difference between both monetary union experiences (i.e., the Latin and the Scandinavian) and the European Monetary Union is that in the former ones, the respective currencies of the members of the monetary union did not disappear. This is the main reason why any parallelism between the Latin and the Scandinavian currency unions and the EMU has to be approached with care.

45. For example, according to Philip R. Lane, "the expansion in cross-border financial positions for the advanced-economy group . . . rose from $68.4 \%$ [GDP] in 1980 to a peak of $438.2 \%$ [GDP] in $2007 \ldots$. While the IFI ratio plunged in 2008 , it subsequently recovered during 2009-2010." Philip R. Lane, Financial Globalisation and the Crisis 3 (Bank for Int'l Settlements (BIS), Working Paper No. 379, 2012). Another measure of financial markets' current hypertrophy is the growth that the derivatives markets has experienced in the last 15 years; thus according to A Rashad Abdel-khalik and Po-Chang Chen "[d]uring the fifteenyear period between 1995 and 2012 , total amounts of financial derivatives have increased by $1,200 \%$, a rate that significantly outpaces the growth of both the [World GDP] (240\%) and US GDP] (212\%)." A. Rashad Abel-khalik \& Po-Chang Chen, Growth in Financial Derivatives: The Public Policy and Accounting Incentives, J. ACCT. \& PUB. POL'Y, at 1 (forthcoming 2015). According to the same authors, the volumes in OTC derivatives for 1995 and 2012 were, respectively, of $\$ 57.5$ trillion and $\$ 696$ trillion, while the world GDP was, respectively, of $\$ 30.2$ trillion and $\$ 72.4$ trillion. Id. at $1-2$. This means that while in 1995 , OTC derivatives volumes amounted to more or less two times the world GDP volume, in 2012 they amounted to more or less ten times the World GDP volume.

46. See Generally Michael D. Bordo \& Lars Jonung, The Future of EMU: What Does the History of Monetary Unions Tell Us? (Nat'l Bureau of Econ. Research, Working Paper No. 
In this section, I will compare two of the cases suggested by Bootle et al. that could be useful for this discussion. These cases are Argentina from 2001 to 2002 and South Korea in 1997. Argentina is a clear case in which a country left a currency board. In turn, Korea is a case of a country breaking not a currency board but a peg with the dollar. Currency boards and pegs are, of course, not monetary unions, but, taking into account that there are no cases of countries leaving monetary unions, they can be used as useful proxies of them.

\section{A. Argentina 2001-2002}

Argentina experienced an unprecedented economic boom during the 1990s, particularly, from 1992 to 1998 . However, for many observers, at the same time the boom was taking place, Argentina was planting the seeds of a serious economic downturn in the late 1990s. The Argentinian economy was hit by the 1998 recession with a number of structural vulnerabilities. These vulnerabilities included increasing public debt, low share and high concentration of exports, the economy's reliance on external savings, and a very rigid labor market. The "currency board" is also cited among the vulnerabilities of the Argentinian economy of the time, but how this affected the unfolding of the crisis in that country is less clear.

In this context, the East Asian crisis exploded in 1997. It spread to a number of countries, in particular, to Brazil, which devalued its currency (the real) in 1999. This had a direct effect on Argentina: exports went down, interest rates up, and internal demand contracted in this country. Due to the labor market rigidity, inflation initiated an increasing trend, and the spreads of the Argentinian bonds started to grow, as compared to the spreads of other economies in the region. The economy entered into depression in 1999-2000, and Argentina seemed to be trapped in a downward spiral of high prices, low growth, and soaring public debt, among other problems. In particular, public debt increased by more than ten basis points from 2001 to 2002 (see Figure 5, infra p. 356) ${ }^{47}$ Further, as the economy was very marginally export oriented, exit through that

7365, 1999) (using the historical records of other monetary unions to predict the outcome of the EMU).

47. According to the IMF, Argentina "doubled" its public debt/GDP ratio from 1992 to 2001. In 1992, Argentina public debt was of $30.7 \%$, in 2001 , it was of $62 \%$. Compared to current debt/GDP ratios in euro-zone countries like Spain, Argentina's figure may not seem very remarkable. However, more important than that is the negative trend that these data reveal in terms of public debt to GDP ratios in this country. IMF, ARGENTINA: STAFF REPORT FOR THE 2002 ARTICLE IV CONSULTATION 31 (Dec. 17, 2002), available at http://www.imf.org/external/pubs/ft/scr/2003/cr03226.pdf. 
door was not possible in the short run. The only alternative was to leave the currency board.

Figure 5: Argentina government debt (1998-2008)

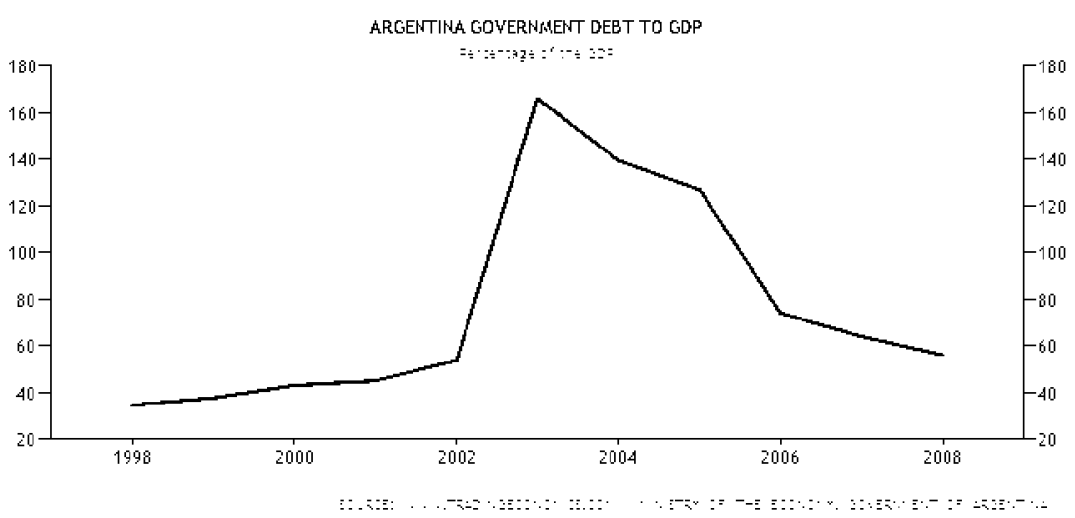

Source: Argentina Government Debt to GDP, TRADING ECON.,

http:/www.tradingeconomics.com/argentina/government-debt-to-gdp (last visited Apr. 1, 2015).

It is, however, very interesting to see how the main international institutions resisted the option of leaving the currency board. For example, in its "Lessons from the Argentinian Crisis" of 2003, the IMF stated the following:

Exiting the currency board via dollarization would not have solved this dilemma, while a float - which could have helped, in principle, to jumpstart the economy through a large depreciation-would have had major adverse repercussions via domestic balance sheets (including the public sector's large dollar denominated liabilities). ${ }^{48}$

As a matter of fact, IMF help was initially oriented toward supporting the currency board, until the Argentinian government realized that this was a daunting task. Therefore, President Duhalde (the fifth president Argentina had had in three weeks) confirmed in January 2002 the debt moratorium that had been declared by President Rodriguez Saá on December 23, 2001. More importantly for our purposes, under the leadership of Roberto Lavagna (who would afterwards be appointed

48. ImF Pol'y Dev. \& Rev. DeP’t, Lessons From the Crisis in Argentina 58 (Oct. 8 , 2003). 
Minister of Economy), President Duhalde made the decision to leave the currency board. ${ }^{49}$ The IMF opposed these decisions, since in its opinion they "complicated any eventual resolution of the crisis." 50 Indeed, the immediate consequences of these decisions were harsh for the Argentinian economy: in 2002, GDP fell to -11 percent, unemployment rose to around 18 percent, and the inflation rate peaked to 40 percent. As to the exchange rate, in March 25, 2002, the peso reached a peak of 4 Argentinian pesos per dollar (see Figure 6, infra p. 358).51 Finally, in terms of equality of income distribution, the country was negatively hit by the crisis. Therefore in 1999, when the crisis started in Argentina, this country's GINI index was 49.81. From that point it started an increasing tendency, which had its highest peak in 2003, when Argentina reached a GINI index of 54.72.

\section{Figure 6: U.S. dollar and Argentinian Peso exchange rate (1999- 2004)}

ARGEHTINEAN PESO

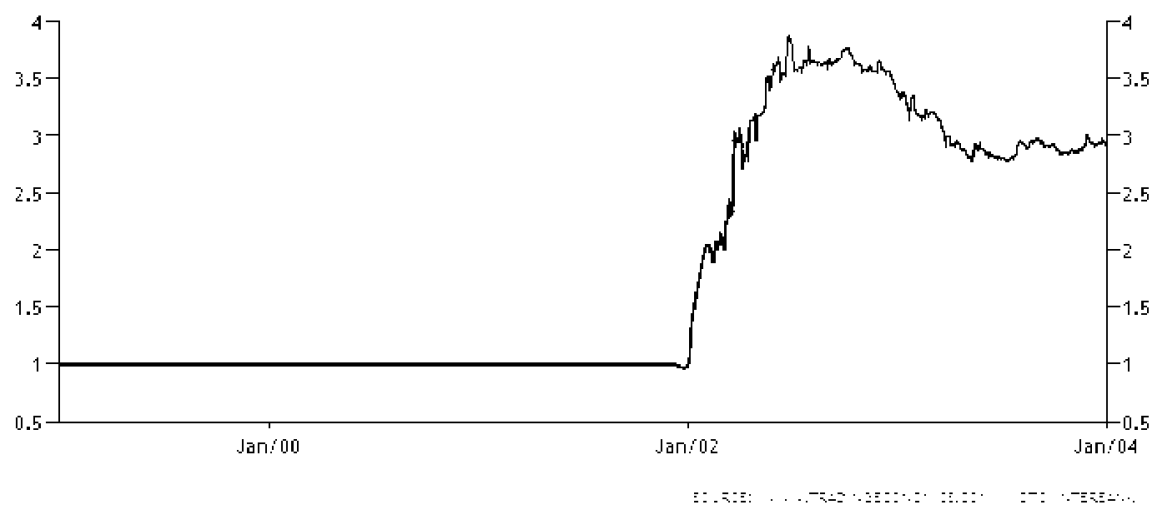

Source: Argentinian Peso, TRADING ECON., http:/www.trading economics.com/argentina/currency (last visited Apr. 1, 2015).

49. The law that served as the basis for this decision was the Ley de Emergencia Pública $y$ de Reforma del Régimen Cambiario LLaw for the public emergency and reform of the rate exchange system]. Law No. 25561, Jan. 6, 2002 (Arg.), available at http://www.mecon.gov.ar/digesto/leyes/ley25561.htm.

50. See IMF POL'Y DEV. \& REV. DEP'T, supra note 48, at 62.

51. See IMF, supra note 47 , at 51 . Considering that the peso was at par with the dollar (1 peso-1 dollar) after the break-up of the convertibility, this means a nominal depreciation of $400 \%$. In real exchange rate terms, the peso suffered a depreciation of $54.7 \%$ in 2002 . Id. at 41 . However, these figures pale if they are compared with the current Argentina Central Bank reference exchange rate between the peso and the dollar, which is 8:4 pesos for a dollar at the time of this writing. 
However, in 2003, Argentina came out of the crisis. Due to devaluation, exports started growing. This had an immediate effect on GDP, which soared to 8.8 percent in 2003 . With regard to unemployment, in 2003 it was already below 16 percent, and it stabilized at around 8 percent as of 2008. Regarding inflation, it stabilized to around 4 percent in 2003 (see Figure 7, infra p. 359). Clearly, high inflation, besides unemployment, was the main battlefield in this country after the crisis of 2001-2002. Finally, in terms of equality, in 2004, the country had almost returned to the pre-crisis situation (GINI of 50.2). Since then, the GINI index has decreased and, in 2010, was at its lowest level (GINI of 43.6) since 1992 (see Figure 8, infra p. 359).

Figure 7: Argentina's inflation (1999-2014)

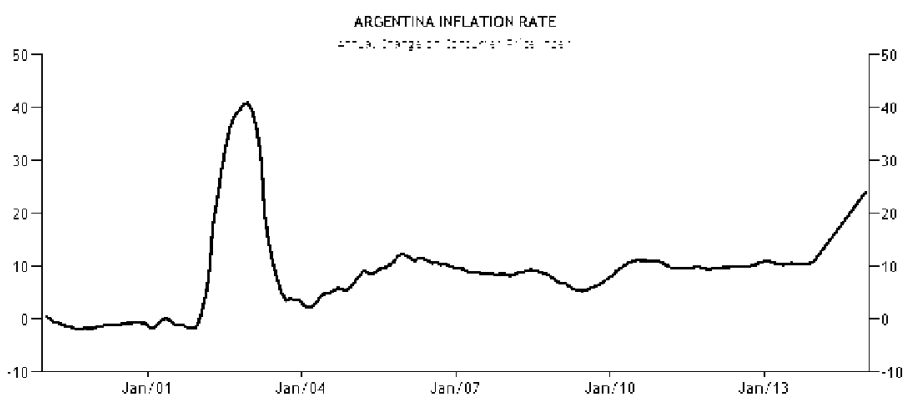

Source: Argentina Inflation Rate, TRADING ECON., http:/www.tradingeconomies.com/ argentina/inflation-cpi (last visited Apr. 1, 2015). 


\section{Figure 8: Argentina's GINI index (1992-2011)}

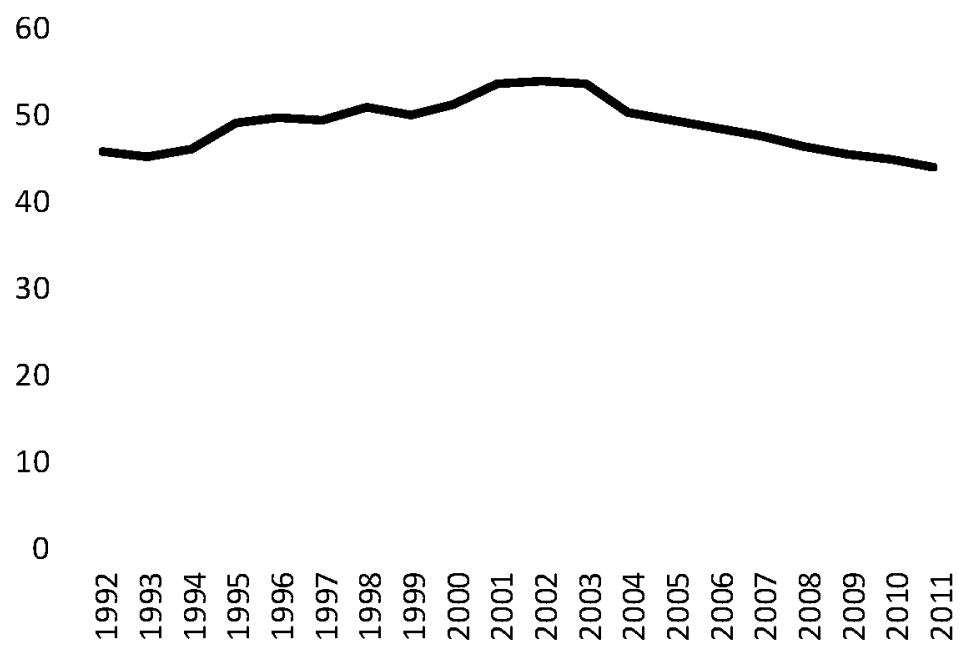

Source: GINI Index (World Bank Estimate), WORLD BANK, http://data.worldbank.org/ indicator/SI.POV.GINI/countries/1W-AR?display=default (last visited Apr. 1, 2015).

\section{B. Korea 1997}

The Korean crisis that started in 1997 offers another interesting example of the effects of devaluation on a depressed economy. It is, however, important to mention that the situation in Korea and Argentina differ in one important aspect: where in Argentina there was a currency board, Korea only had its national currency (the won) pegged, with a certain degree of flexibility, to the dollar before the crisis exploded in 1997. This is the point that Stanley makes. In his account of the different approaches to the Argentinian and Korean crises (1997-2002), he indicates that "until 1995, Korea remained pegged . . . to the dollar. After that date, exchange rate flexibility went up considerably." 52 Therefore, whereas the Argentinian economy was dollarized before the crisis started in that country, the Korean economy was not. It follows that withdrawing from the currency board had a very different meaning for Argentina than devaluating did for Korea.

Korea is another case in which the crisis was preceded by a large period of intense economic growth. As happened in Argentina, this extraordinary growth probably masked the main vulnerabilities of the

52. Leonardo E. Stanley, Capital Inflows, Bank Deregulation and Financial Institutions: From Repression to Crash? Argentina and South Korea Compared 15-16 (Working Group on Dev. and Env't in the Americas, Discussion Paper No. 32, 2011). 
Korean economy. According to the literature on the Korean crisis, these vulnerabilities were, basically, of two kinds: first, Korea had a feeble financial system, and second, it also had a very weak corporate management system. As often happens, both trends were mutually reinforcing. In practice, capital inflows to Korea were "directed" by the government to finance big family conglomerates, the so-called "chaebols." The system was so corrupt that authors, such as Kang, ${ }^{53}$ have constructed the concept of "crony capitalism" on the ashes of the Korean example. As financial management was very weak, the government could decide what conglomerates deserved to be financed and which firms did not. The "chaebols" received financial assistance that was, in many cases, irrespective of their performance. The financial assistance was also used as an instrument for political financing.

In any case, the Korean private sector was already highly leveraged in the mid-1990s. This is also one of the main differences between the Argentinian case and the Korean case. While in Argentina the public debt was soaring before the crisis, the problem in Korea was not one of public debt but rather of private debt. For example, Figure 9 shows that the domestic credit to the private sector experienced an important increase from 1994 to 1996. Instead, government debt remained, in the period before the crisis broke up, at very reasonable levels (see Figure 10, infra p. 361). In addition to this, Kim and Chang indicate that the debt to equity ratio was also problematic at the time of the crisis (338 percent between 1973 and 1996). 54

Further, Korean banks were very indebted in the short run, whereas Korean big conglomerates were leveraged in the long run. In this vein, Chan, Park, and Yoo report that from 1994 to 1996, 64 percent of the total foreign borrowing was short term, and 85 percent of the lending was long term. ${ }^{55}$ On top of that, the government issued a number of signals in the 1990s, assuring that it would not let the conglomerates fall. This implicit guarantee added to the capacity of the conglomerates to finance themselves at low costs and artificially expand beyond market constraints.

53. See generally, DAVID C. KANG, CRONY CAPITALISM: CORRuPTION AND DEVELOPMENT IN SOUth KOREA AND THE PHILIPPINES (2002) (discussing the negative effects that political corruption have had on the development of the South Korean economy).

54. Ginil Kim \& Doug Joo Chang, Rethinking the Causes of the Korean Currency Crisis of 1997, 18.2 KOREAN J. ECON. 360, 362 (2011).

55. Ha-Joon Chang, Hong-Jae Park \& Chul Gyue Yoo, Interpreting the Korean Crisis: Financial Liberalisation, Industrial Policy and Corporate Governance, 22 CAMBRIDGE J. ECON. 735, 739 (1998). 


\section{Figure 9: South Korea domestic credit to the private sector} (1990-2002)

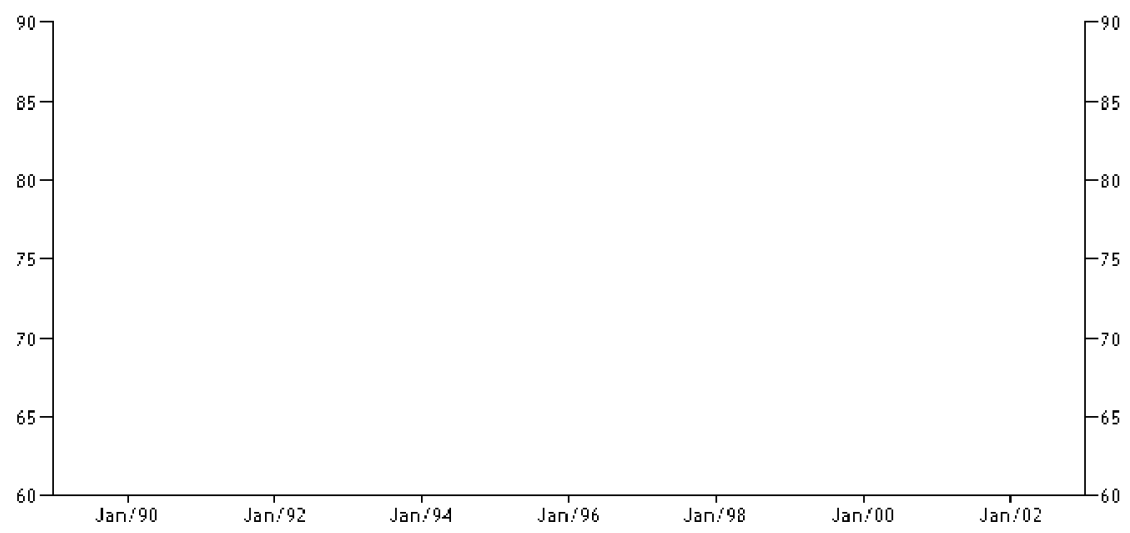

Source: Domestic Credit to Private Sector (\% of GDP) in South Korea, TRADING EConomics, http:/www.tradingeconomics.com/south-korea/domestic-credit-to-private-sector-percent-ofgdp-wb-data.html (last visited Apr. 1, 2015).

Figure 10: South Korea government debt (1996-2008)

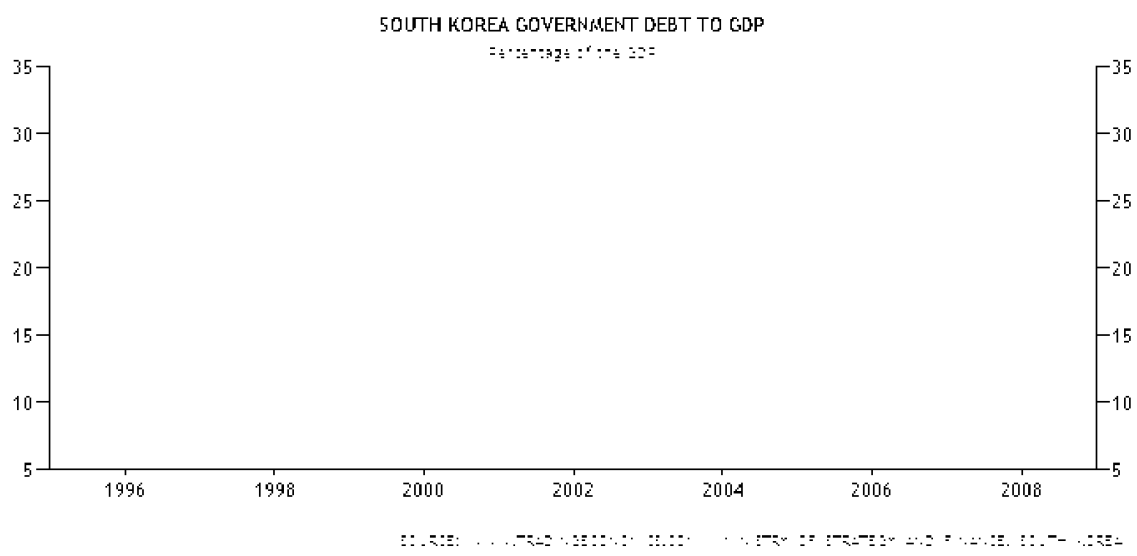

Source: South Korea Government Debt to GDP, TRADING ECON., http:/www.trading economics.com/south-korea/government-debt-to-gdp (last visited Apr. 1, 2015).

This was the economic situation in Korea when the currency crisis of the East Asian countries unfolded. The devaluation of the Thai baht in July 1997 rapidly infected the rest of the countries in the area. At first it seemed that Korea would be sheltered from the crisis. But, as interbank credit shrunk, Korean banks started suffering. The credit crunch affected 
the big Korean conglomerates, and some of them in fact went bankrupt. This harmed the good health of the Korean economy and reduced the overall credibility of the country. It seemed that Korean firms could in fact go bankrupt after all.

In turn, the Korean won started a free fall in September and October of 1997. According to the IMF account of the Korean crisis, the depreciation was initially very gradual, but, already by December, one dollar was exchanged for 2,000 wons (where in September of the same year it was traded at 910 wons per U.S. dollar) (see Figure 11, infra p. 363). In fact the first action taken by the IMF (when it was called in to assist the country) and the Korean government was aimed at stabilizing the currency. In the words of the IMF, the rescue package was oriented toward avoiding the devaluation and inflation spiral that had been experienced in past cases. In this respect, the IMF recommended implementing very tight monetary and fiscal policies. Therefore, interest rates increased, and the currency was stabilized (and even appreciated in the following months). However, the literature on the Korean crisis is divided on the question of the causes that prompted the stabilization of the won. For the IMF, this was an immediate effect of the austerity fiscal and monetary policies. It even finds correlation between the increase in interest rates and the stabilization of the won. Instead, Furman and Stiglitz find that the connection between both variables is unclear. For these authors:

[A] range of other factors helped to stabilize these Asian currencies, including the appreciation of the yen, changes in the governments of all three countries, disbursements of official foreign financial support ... . the restructuring of IMF programs away from overly strict fiscal policies and immediate bank recapitalization, and the restructuring of Korea's commercial bank debt. Again, high interest rates may have helped support the stronger currencies, but the magnitude of the effect was probably not that large. 56

Be it as it may, Stanley remarks that the effects of the depreciation of the Korean won were soon to be noticed. According to him, this generated an important export recovery, which created a surplus of 41.7 billion dollars. This in turn allowed the building of an important buffer of foreign exchange reserves. In the aftermath of the crisis, in 1998, Korea's GDP decreased to an unprecedented -6.65 percent. However, the GDP experienced an impressive growth of 10.5 percent shortly after in 1999. In

56. See Jason Furman \& Joseph E. Stiglitz, Economic Crises: Evidence and Insights from East Asia, 2 BROOKINGS PAPERS ON ECONOMIC ACTIVITY 1, 121 (1998). 
regard to unemployment, it peaked to a historical 8.6 percent at the beginning of 1999 . However, Korea closed that year with a 6.3 percent level. Since then it has remained stable between 3 percent and 4 percent. As per inflation, it is important to mention that Korea entered the 1997 crisis with a more flexible labor market than Argentina. Therefore, devaluation was not translated into a rise in labor costs, so inflation was kept under control. Thus in 1998, the inflation rate increased to around 7 percent. However in 1999 it decreased to less than 1 percent to further stabilize between 2 percent and 4 percent in the next years (see Figure 12, infra p. 364). It is also important to mention, in this regard, that one of the conditions required by the IMF financial package was to establish CPI inflation targeting, which Korea has done since 1998. ${ }^{57}$ Last but not least, in terms of equality, Cheon and others report that inequality of income distribution was low in Korea before the 1997 crisis (GINI index of 0.26 in 1996). When the crisis hit the country, inequality started a rising tendency (GINI index of 0.29 in 1998) to descend to almost pre-crisis levels (GINI index of 0.27 ) in 2009. However, these authors also point out that after 2003 inequalities have experienced a rebound in this country, so that the GINI index was 0.31 in 2011.58

\section{Figure 11: Won exchange rate to the dollar (1995-2001)}

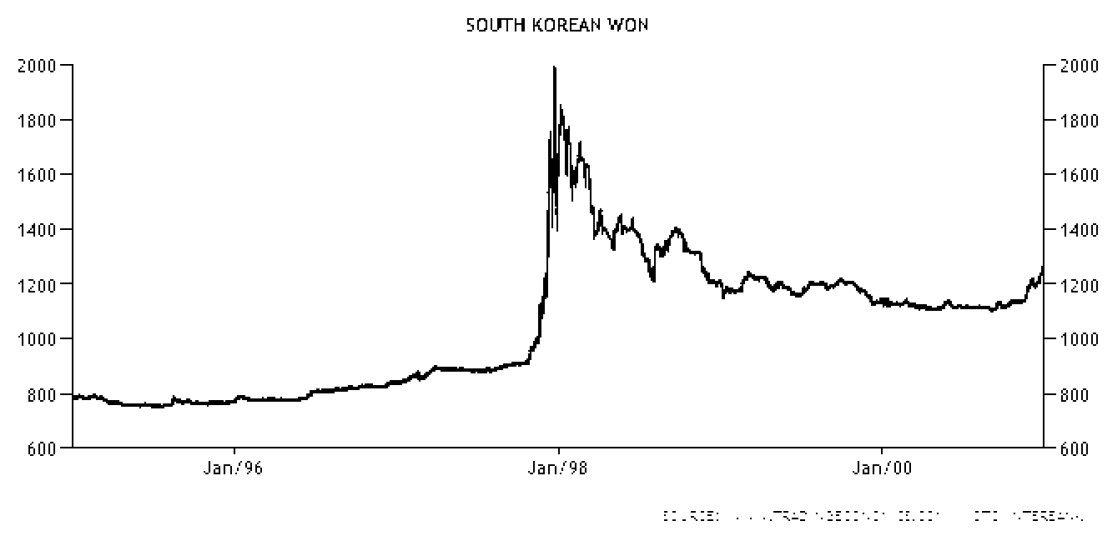

Source: South Korean Won, TRADING ECON., http:/www.tradingeconomics.com/southkorea/currency (last visited Apr. 1, 2015).

57. See Alexander W. Hoffmaister, Inflation Targeting in Korea: an Empirical Exploration (IMF, Working Paper No. 99/7, 1999) (describing different methods and success rates of inflation measurement systems in South Korea).

58. CheON et al., Growing Inequality and its Impacts in Korea, Growing INEQUALITIES' IMPACTS (GINI) 90 (2013), available at http://giniresearch.org/system/ uploads/439/original/Korea.pdf? 1370077269. 


\section{Figure 12: Korea's inflation consumer price index (annual percent change)}

Source: Inflation, consumer prices (annual \%), WORLD BANK, http://data.worldbank. org/indicator/FP.CPI.TOTL.ZG/countries/KR?display-graph ((last visited Apr. 1, 2015).

\section{Parallelisms and Differences}

The conclusions we may extract from the comparison between the Argentinian and the Korean cases are complementary. For one, it is clear, as Stanley suggests, that the depreciation of the Korean won from September to December 1997 had an important effect in boosting exports. However, the effects of devaluation were less clear in the Korean case than in the Argentinian case since the currency had recuperated at least part of its exchange value by 1998. Furthermore, in the Korean case, there was no default (not even partial default).

The Korean and Argentinian cases both differ from and equal the Spanish case. They differ in the sense that Korea did not have a public debt problem when the crisis started, nor as the crisis unraveled. Spain did not have a public debt problem when the crisis started, but it did in time. Argentina did have a public debt problem at the beginning of its crisis (at least in trajectory). But the Korean case is similar to Spain in the sense that when the crisis started, Korea had a private debt problem (as Spain did at the beginning of the crisis) (see Figure 13, infra p. 365).

In more general terms, one could argue that currency disequilibrium during the last part of 1997 was in Korea more an effect of the overall East-Asian crisis that had started in Thailand and not so much a cause of it. However, in the Argentinian case, it is clear that the currency board was to an important extent a catalyzer of the ensuing crisis. The IMF tried both in the Argentinian case and in the Korean case to stabilize the currency; however, in the latter case it was more successful whereas in the former it was not. Accordingly, the Argentinian government broke up the currency board, which proved to be crucial for the ultimate recovery of the 
country, whereas in the Korean case a depreciated but stabilized won was a starter for economic recovery.

The Argentinian and the Korean cases also differ in another important aspect, that is, in structural reforms. Korea adopted structural reforms. They were mainly oriented at breaking and eliminating the "chaebols" system. The structural changes were successful in reforming its corporate and banking systems. However, unlike Korea, Argentina did not embark on a sustained path of structural reforms. Sound and sustainable structural reforms may be at the heart of the differences in performance of each of these economies some years after the crisis and even today. Currently, where Korea is still a promising economy, one that does not present serious macroeconomic challenges, Argentina may instead be on the verge of a new economic downturn. The lesson from this seems to be clear: devaluing, breaking a peg, and leaving a currency board or even a monetary union would be useless in the absence of more in-depth structural reforms. However, what is still unclear is which exact blend of reforms is the appropriate one for a given country.

Figure 13: Public, private, and accumulated (public + private) debt in Spain, annual percent to GDP

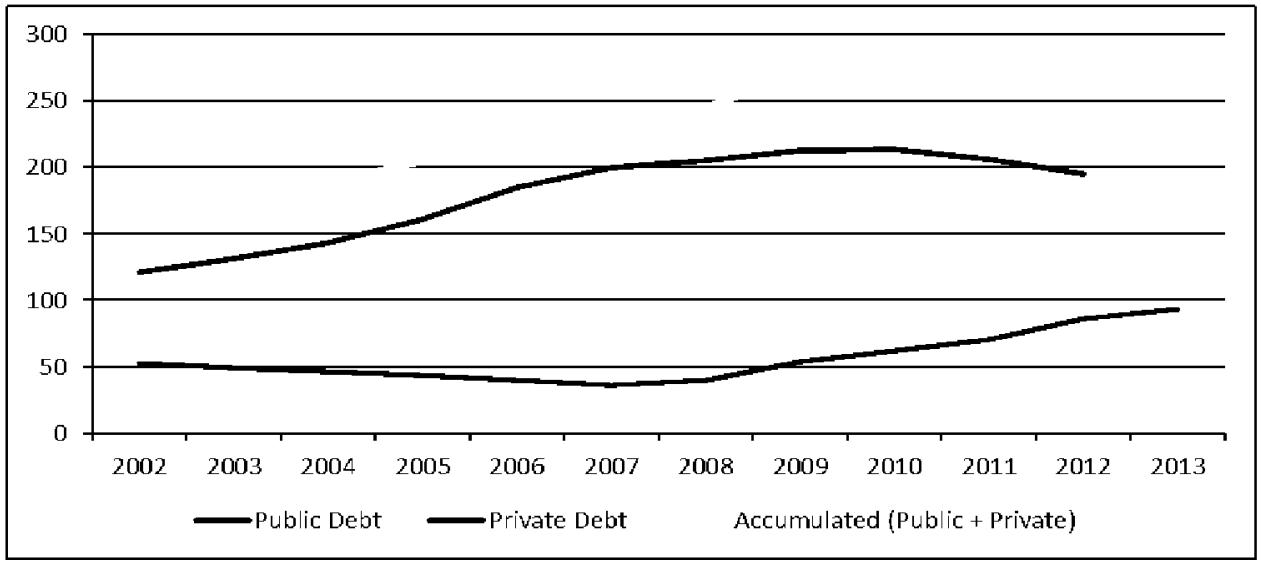

Source: Eurostat (2002-2013).

\section{Time And The Distribution Of The Costs Of Economic AdJustment}

The third important determinant that a country that is in the middle of an economic depression has to take into consideration when thinking about exit from a currency union is the time factor. When is the time ripe for considering such an event? 
In this sense, when analyzing the Argentinian crisis of 2001-2002, Hausmann and Velasco ${ }^{59}$ underline the importance that the real exchange rate, the financial stress of the country, and its export prospects had in accounting for the crisis. According to these authors,"To make sense of what went wrong, one has to focus on the interaction of two factors: real exchange rates . . . and the country's capacity to borrow abroad . . . In our framework, export prospects determine the access of financially constrained countries to external resources." 60 Interestingly, one of the main conclusions both authors reach is that Argentina's decision to break the currency board was a good decision made at the wrong time. According to the authors, Argentina should have broken the currency board well before it finally did. ${ }^{61}$

The main implication derived from Haussmann and Velasco is that when the three previously mentioned variables enter into a downward spiral, the state that is suffering such hardship should react immediately by devaluing its currency, or in our case, by exiting the monetary area. "The sooner, the better" seems to be Haussmann and Velasco's main implication. So let us apply Haussmann and Velasco's scheme to the Spanish case. For example, in 2013, Spain's real effective exchange rate was around 0.30 points above the German one-in general terms, at least since 2005, Spain has been suffering from an endemic currency overvaluation problem when compared to other EU countries, and in particular, when compared to Germany (see Figure 14, infra p. 367).

59. See generally Ricardo Hausmann \& Andrés Velasco, Hard Money's Soft Underbelly: Understanding the Argentine Crisis, BROOKINGS TRADE FORUM (2002) (describing several of the underlying fiscal issues that led to and exacerbated the Argentine debt crisis).

60. Id. at 5 .

61. Id. at 29 . 
Figure 14: Real Effective Exchange Rate, Spain, Germany, France, Greece $^{62}$

100.1

100

99.9

99.8

99.7

99.6

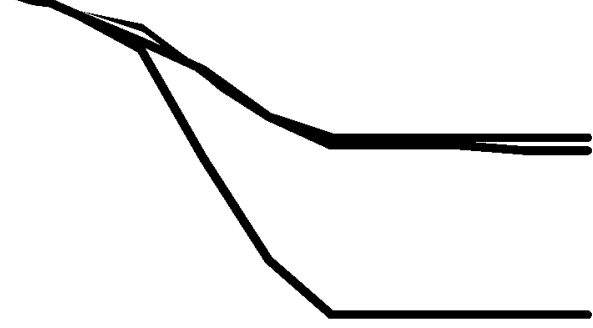

Spain

99.5

99.4

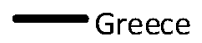

99.3

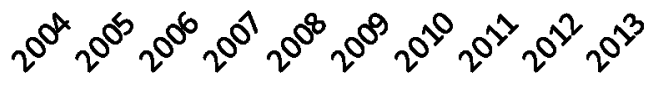

Source: Eurostat (2014).

Furthermore, once the economic turbulences started in 2007-2008, Spanish spreads started to grow from "huge to the obscene," to use the same expression that Haussmann and Velasco used for the Argentinian case. ${ }^{63}$ It is important to remember once again that, although at this point Spain did not have a public debt problem, it did have a problem of private debt (see Figure 13, supra p. 365). Thus the Spanish risk premium in April 12, 2010, was 67 basis points; however, in just one month (by May 7 , 2010), it had escalated to 162 basis points, and in June 25, 2012, when Spain formally requested a bailout for its banking sector, the Spanish risk premium was 516 basis points. ${ }^{64}$ It would reach its highest historical point

62. REER (Real Effective Exchange Rate) is defined as a variable that "measures the development of the real value of a country's currency against the basket of the trading partners of the country." Zsolt Darvas, Real effective exchange rates for 178 countries: A new database 1 (Bruegel Working Paper No. 2012/06, 2012), available at http:/www.bruegel.org/download/parent/716-real-effective-exchange-rates-for-178-countriesa-new-database/file/1630-real-effective-exchange-rates-for-178-countries-a-new-database/.

This variable is used for a number of purposes, inter alia, assessing the equilibrium value of a currency, the change in price or cost competitiveness, the drivers of trade flows, or incentives for reallocation production between the tradable and the non-tradable sectors. I use this measure in the first sense indicated above. See id.

63. See Hausmann \& Velasco, supra note 59 , at 6 .

64. See España solicita formalmente asistencia financiera para la banca española [Spain Formally Solicits Financial Assistance for the Spanish Banking Sector], MINISTERIO DE 
in July 24, 2012 (637 basis points). After the now famous Draghi declaration of August 2012 ("the ECB will do whatever it takes to save the euro") ${ }^{65}$ the spreads have decreased, stabilizing around 200 basis points (at the time of this writing, October 2014, they are around 150 basis points) (see Figure 15, infra p. 368).

Figure 15: Spain risk premium (spread between the 10-year Spanish government bond, and the 10-year German bond) 20072013

Premium

600

300

2007

2008

2009

2010

2011

2012

2013

Source: See Spain Risk Premium, COUNTRYECONOMY.COM, http//countryeconomy.com/ riskpremium/spain (last visited Apr. 1, 2015).

What about Spanish export prospects? Since the crisis started in 2007 , Spain has experienced a considerable reduction in its current account deficit. In 2009, the Spanish current account deficit was 50.5 billion euros, while in 2012 it was 11.5 billion euros. IMF reports, however, indicate that in 2013 Spain witnessed the first current account surplus since it joined

\footnotetext{
ECONOMÍA U COMETITIVIDAD (June 25, 2012) http:/www.lne.es/ elementosWeb/gestionCajas/MMP/File/cartaayuda.pdf (exhibiting the text of the formal letter of request for financial assistance).

65. See Draghi, supra note 27.
} 
the euro (1 percent GDP), and it estimates that this trend will even reinforce in the next years. ${ }^{66}$ All this seems to point in the right direction.

However, a closer look gives ground for a more nuanced and less optimistic analysis. As the IMF points out, the Spanish export sector is now behaving worse than it was expected. Thus, after the rebound that exports experienced from 2012 to 2013 , the exports prospects will stabilize or even decline, according to the IMF estimates, until 2019. This happens in a context in which imports are behaving better, due to the increase in domestic demand. However, the domestic demand prospects will only slightly ameliorate as far as the IMF estimates go. In addition, if one takes into account the impressive public and private accumulated debt that Spain holds, as well as its austerity policies, then it comes as no surprise that all international institution forecasts of Spanish growth keep insisting that the recent Spanish economic recovery remains fragile. Thus, according again to the IMF, Spain would have timidly started to grow at the end of 2013. Although this growth trend would tend to consolidate in the years to come, the growth rate would be rather thin, at least until 2019 (2 percent) ${ }^{67}$

66. See IMF, Spain: StaFF REPORT FOR the 2014 ARticle IV CONSUltation 41 (IMF Country Report No. 14/192, 2014).

67. To the best of my knowledge, the most updated computation of the growth threshold needed by the Spanish economy to create net employment is the work of Patricia de Cea et al., Output Growth Thresholds for Job Creation and Unemployment Reduction in Spain 15 (2013) (unpublished manuscript), available at http://baobab.uc3m.es/monet/ monnet/IMG/pdf/Output_Growth_Thresholds_for_Job_Creation_and_Unemployment_Reducti on_in_Spain_Patricia_de_Cea_Sarabia.pdf (establishing that a GDP growth rate of 1.35\% would allow for net employment creation in Spain and that, in order to stop unemployment from growing, a modest GDP growth rate of $0.26 \%$ would be enough). See also Juan Jose Dolado, Crecimiento del PIB y el empleo [Growth of GDP and Employment] EL PAIS (Jan. 12, 2014), available at http//economia.elpais.com/economia/2014/01/11/ actualidad/1389472783_657936.html (lowering the threshold established in Patricia de Cea's article and arguing that it would be enough with a GDP growth rate of $1 \%$ to create net employment -he however argues that a rate of $0.3 \%$ would be necessary to stop unemployment from growing-). See also Daniel Fuentes Castro, ¿Cuánto tiene que crecer la economía española para generar empleo? [How Much does the Spanish Economy Have to Grow to Generate Employment?], WWW.ELDIARIO.ES (Mar. 5, 2014, 8:36 AM), available at http://www.eldiario.es/zonacritica/crecer-economia-espanola-generar-empleo_6_ $233486658 \mathrm{html}$ (casting doubts as to the soundness of the previous figures). 


\section{Figure 16: Spain's exports of goods and services, internal demand, and GDP growth (percentage of change) 2010-2019}

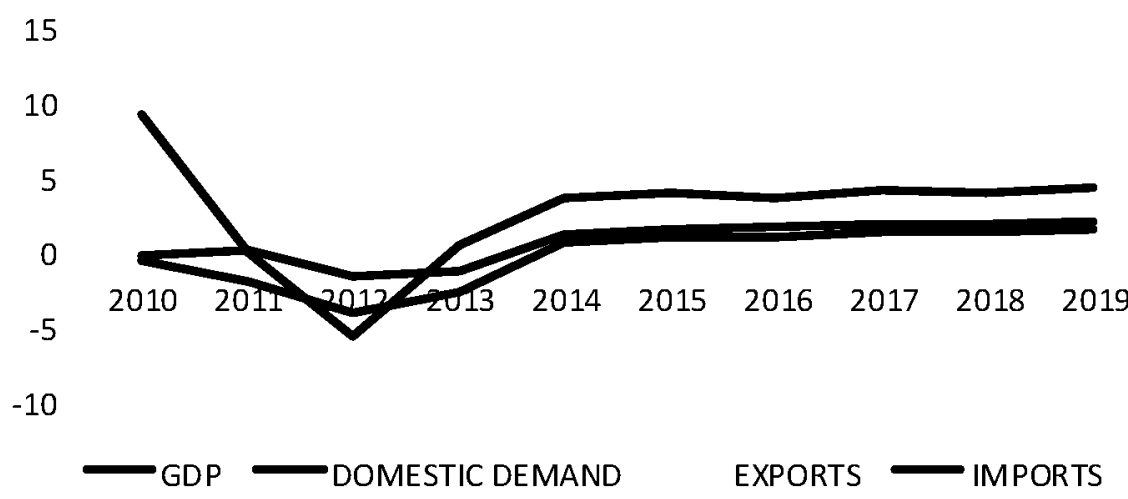

Source: IMF: Spain 2014 Article IV Consultation (July 2014).

The main consequences derived from the previous picture are not only of macroeconomic significance. They also have a social dimension, and this is the fourth element I would add to Haussman and Velascos's triad. I refer, in particular, to the redistribution of the costs of economic adjustment that has to take place in the middle of the storm. When the risk is too high that these costs will be distributed in a more uneven way than in the alternative exit scenario, then the alternative should be considered. Equality considerations are not only based on moral grounds, but inequality may also have an impact on growth. ${ }^{68}$ For example, in the

68. Thomas Piketty, Capital in the Twenty-Finst Century (Arthur Goldhammer trans., Belknap Press ed. 2014) (exploring the growth of wealth and wealth distribution in recent times). However, Piketty's oceanic work does not directly deal with the main consequences that this trend could have in the future for the world or at least for the developed world. Other authors have however engaged in this discussion. See JONATHAN D. OSTRY ET AL., REDISTRIBUTION, INEQUALITY, AND GROWTH 4 (IMF Staff Discussion Note SDN/14/02, 2014) (analyzing the question of whether inequality is negatively correlated to growth. According to these authors, "lower net inequality seems to drive faster and more durable growth for a given level of redistribution.") Still other authors have analyzed the impact of inequality not on growth but on societies' well-being and prosperity. See RICHARD

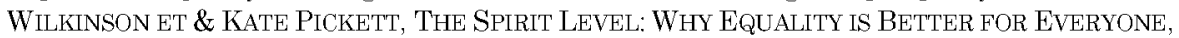
(Penguin ed. 2010) (finding correlation between inequality and poor health performance (among other indicators of social well-being)). Whatever the merit of all these works, it is submitted that they probably fail to address, at least in a more direct way, what is the most important facet in the debate on inequality: its potential for domination or exploitation. Piketty's work only very indirectly addresses this issue. According to him, high inequality indexes are worrisome since they have a potential to become "socially destabilising." PIKETTY, supra, at 10 . The sense in which inequality can be socially destabilizing is however not further discussed in Piketty's and it is probably more clearly expressed in Marx's Capital (whom 
Spanish case, the country was the second most unequal country of both the Eurozone and the European Union in 2012, right behind Latvia. Thus, if we take the GINI coefficient (see Figure 17, infra p. 371), Spain had a coefficient of 35 and Latvia of 35.7. A more worrisome point that is illustrated in Figure 18 is that after a period of relatively consistent reduction of inequalities in the country, at least as measured by the GINI index, the beginning of the crisis in 2008 precisely marked the reversal of the previous trend (Spain's GINI coefficient was 31 in 2004 and, as has been said, 35 in 2012).

\section{Figure 17: GINI index (2012)}

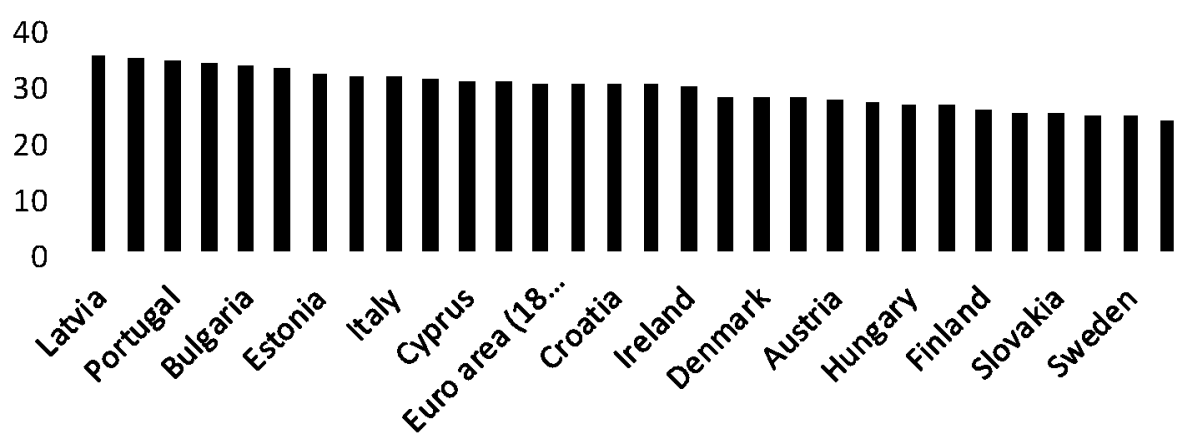

Source: Eurostat (2014).

Piketty cites on this point). See KARL MARX, CAPITAL 490 (Student ed. 2014) (according to whom "the law of capitalistic accumulation, metamorphosed by economists into pretended law of Nature, in reality merely states that the very nature of accumulation excludes every diminution in the degree of exploitation of labour ....") 
Figure 18: GINI index, evolution over time (2005-2012)

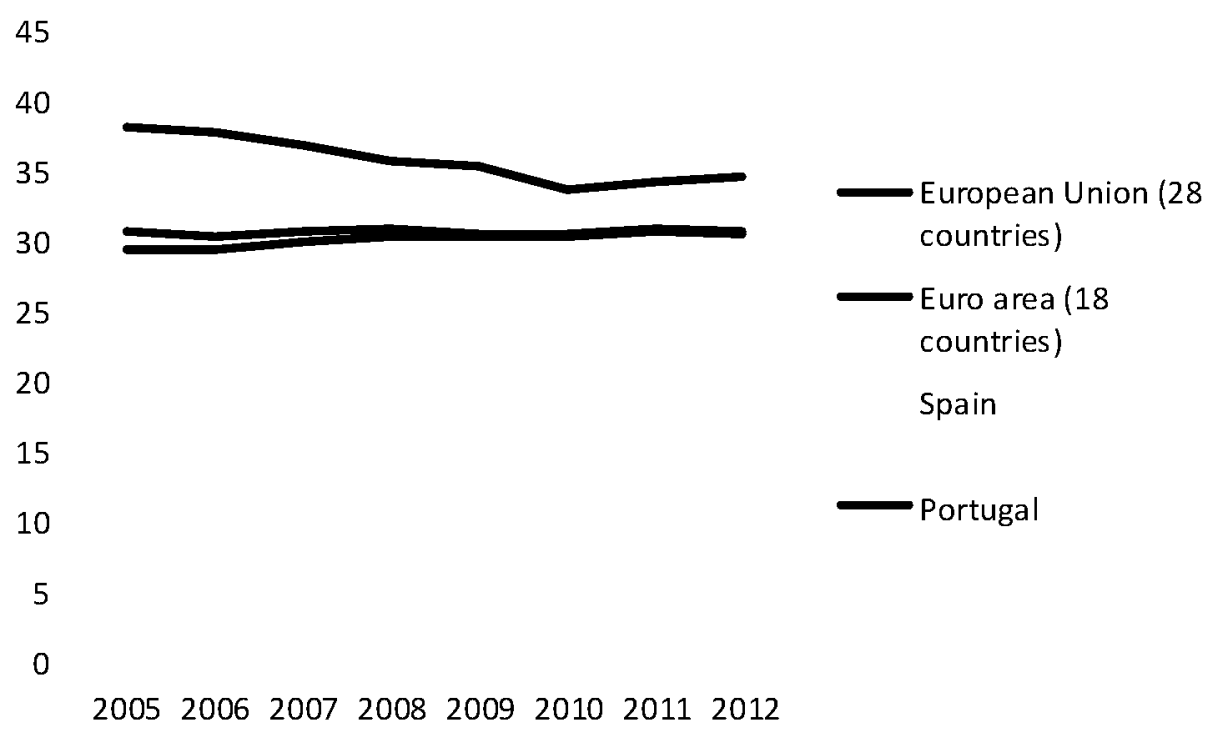

Source: Eurostat (2014).

Furthermore, in regarding not just income distribution but how income is distributed between the richest twenty percent and the eighty percent at the bottom in Spain, the results are also alarming. In this regard, the S80/S20 ratio shows that Spain is the most unequal country in terms of income distribution, this time in both the Eurozone and the European Union (see Figure 19, 2012 data, infra p. 373). Thus the Spanish coefficient in 2012 was 7.2 points (it was 5.2 in 2004), whereas the European Union and the Eurozone average were 5.0 points. It is interesting to note that the analysis of both indexes (GINI and S80/S20) shows a more surprising outcome, which is that although inequality has dramatically increased in Spain since the crisis started, the EU average has remained almost unchanged over the years. (In 2004 the GINI score was 30.0 for the EU, where in 2012, it was 30.4.) The same happens with the S80/S20 index. In 2004 the coefficient was 4.8, whereas in 2012 it was 5.0 . Therefore, it would seem that the crisis does not inexorably mean that equality has to be negatively affected (see Figure 20, infra p. 374).

In this particular respect, it is interesting to take the following example. Portugal, a country severely hit by the crisis (and one that has received a full bailout), not only fares better than Spain in regards to the S80/S20 and GINI indexes, but its position even ameliorated at the beginning of the crisis, although there seems to be a reversal of this trend 
since 2010. The point is that before the crisis, Portugal presented higher GINI and S80/S20 coefficients than Spain. As regards GINI, Portugal had a coefficient of 37.8 in 2004 (Spain's GINI was 31, thus a difference of almost 7 points). In 2012, Portugal's GINI was 34.5, whereas Spain's was 35. And as regards the $\mathrm{S} 80 / \mathrm{S} 20$ index, the numbers are almost swapped for both countries: Portugal's coefficient was 7, whereas Spain's was 5.2 in 2004 (they were, in $2012,5.8$ and 7.2 , respectively). To be sure, unemployment plays a role here: the unemployment rate in Spain being much higher than that in Portugal since the crisis started. Portugal is interesting in this regard, since unemployment has not ceased to grow in this country (granted, to a lesser degree than in Spain) since the crisis exploded. However, even under growing unemployment, inequality is lower in this country than in Spain. In sum, a crisis does not always have to translate into more inequality, but in Spain it has. 69

Figure 19: S80/S20 (2012 data)

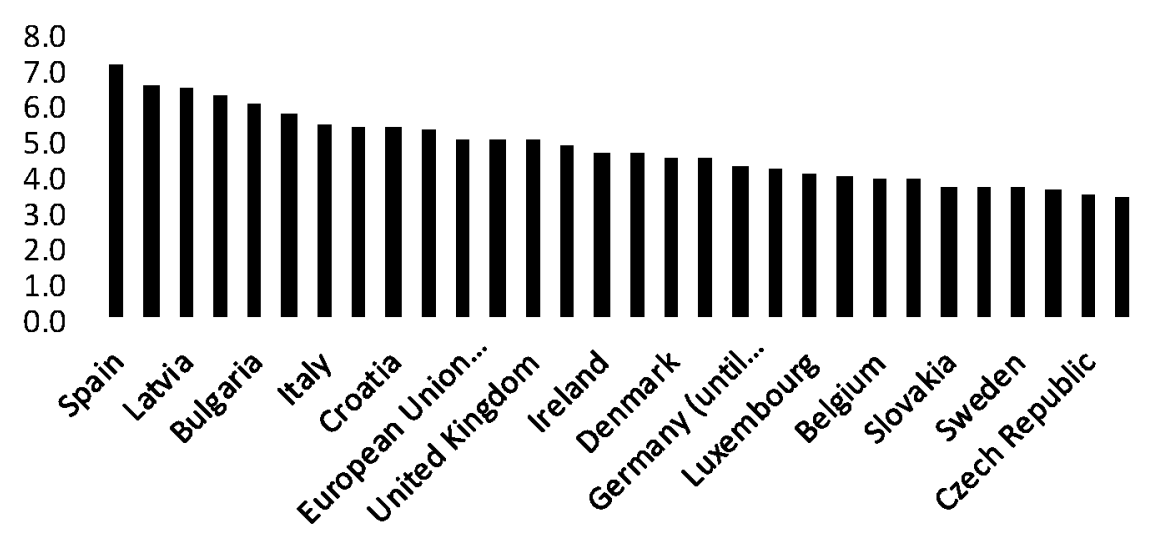

Source: Eurostat (2014).

69. See ADA Ferrer-I-CARboneld et AL., Growing InEQUALities and Its IMPACtS IN SPAIN, GROWING INEQUALITIES' IMPACTS (GINI) 31(2013), available at http:/www.giniresearch.org/system/uploads/612/original/CR-Spain-v2.pdf? 1400771292 (arguing that "although there is a correspondence between unemployment rates and inequality trends, the impact of unemployment onto inequality is not well studied, although the unemployment differences across socio-economic status seems a contributor to inequality"). 


\section{Figure 20: S80/S20 index over time}

7

6

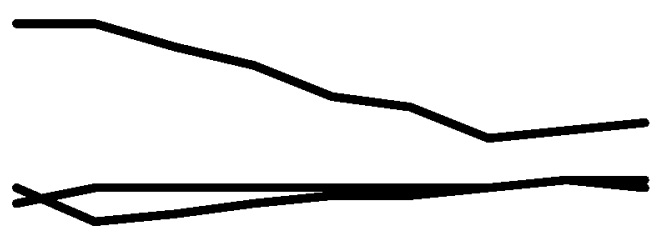

4

European Union (28 countries)

Euro area (18 countries)

Spain

Portugal

0

200420052006200720082009201020112012

Source: Eurostat (2014).

The fact that inequality is growing in Spain is illustrative of another point: the crisis is having winners and losers in this country. It is therefore important to identify which groups belong to each of these categories and how Spain exiting the euro could have an impact on them. Though much research still needs to be done in this area, ${ }^{70}$ at least in theory, it is possible to say that rentiers (people who obtain their income from capital, and within this group, above all savers) are doing much better than people who obtain their income from labor, if we set aside top executives (to whom one could add top sportsmen and women). ${ }^{71}$

70. See Olga Salido Cortés, Los cudadanos españoles ante la crisis [Spanish Citizens Before the Crisis] 36 (Fundación Alternativas, Working Paper No. 178, 2012), available at http:/www.consumo-ccu.es/informes/estudioCiudadanosCrisis.pdf (analyzing how the economic crisis has impacted upon inequality in Spain).

71. I define capital in the way Piketty does in his book. First of all, Piketty excludes, for the right reasons in my opinion, human capital from the rest of capital. Therefore he defines national capital as "the total market value of everything owned by the residents and government of a given country at a given point in time, provided that it can be traded on some market." See PIKETTY, supra note 68, at 48. Basically, Piketty distinguishes between financial (deposits, bonds, stocks, pension funds, etc.) and non-financial capital (real estate, machinery, infrastructure, etc.). Id. He also distinguishes between private and public capital, thus the capital owned by private persons (be them legal persons) and the capital owned by the 
Therefore, leaving the euro would imply a devaluation of the new Spanish currency, and thus, the purchasing power of all these groups would be affected. To give a number of examples, it is clear that income from labor would be affected by the adjustment of the new currency to a different equilibrium in its exchange rate due to depreciation. However, financial assets owners would be affected as well since the value of their assets would be accordingly depreciated. Savings would also be affected by the change of currency and, therefore, by the ensuing depreciation. This is an important point since, as Piketty shows, savings is one of the keys if not the key to understanding the increase of the share of income from capital that Europe has experienced since the 1970s. ${ }^{72}$ Only those Spanish residents who have invested in the euro or in other currencies abroad would be less impacted by the change (and might even benefit from it). ${ }^{73}$ The point is clear: although there would also be losers and winners, exiting the euro would probably have the effect of generating a fairer distribution of the costs of adjustment than its alternative-remaining in it. So if Spain left the euro, more groups would be affected by the adjustment derived from this event; therefore, making it possible to argue that the differential in terms of equality would not be as important as it is today in this country. Exit and devaluation would thus be a fairer shock absorber.

The conclusion that we can draw from this section is at least the following: first, the three variables that Haussman and Velasco point to are the key variables a country has to take into account when deciding to react to adversity through exit. Time will be a crucial element here, since the sooner a state makes up its mind on this issue, the better. However, the benchmark will not only be economic growth, but also how even in both scenarios the share of the adjustment burden will be.

\footnotetext{
government. $I d$. When I refer to the "winners" of the adjustment process that is taking place in Spain (and in other EU countries) I am thinking first and foremost in the former and not in the latter (in private capital rather than in public capital) since, as Piketty shows, while the second one has become stagnant since the 1970 s (when it has not decreased) in Europe, the first one has augmented in a substantial way in this period. Id.

72. See PikeTTY, supra note 68 , at $169-70$.

73. This sector is however not negligible in economic terms. An indication of this is given by the UN CONFERENCE on TRADE AND DEvelopMENT, WORLD INvESTMENT RePORT 209 (2014), available at http://unctad.org/en/PublicationsLibrary/wir2014_en.pdf (according to the UNCTAD, Spanish Foreign Direct Investment outward stock was 643.226 million dollars in 2013 , which represents the equivalent of $46 \%$ of Spanish GDP. As is known, FDI measures investments made abroad by companies or entities from one particular country, in this case, Spain. The volumes are therefore probably larger since FDI does not take into account the assets held by Spanish private persons abroad).
} 


\section{CONCLUSION}

Whether Spain will leave the Eurozone is something that only time will tell. At the time of this writing, Germany and France are experiencing slow economic growth, and Italy is in a new recession. ${ }^{74}$ Furthermore, the whole euro area is probably experiencing a deflationary trend. ${ }^{75}$ In this context, a triple-dip recession in the whole euro area, and in particular in Spain, could not be completely discarded. ${ }^{76}$ The issue of Spain and its membership to the Eurozone could, therefore, reemerge in the close future. In any case, as the previous analysis shows, the country fits well within the profile of countries that historically have had more propensity to leave currency unions (or similar arrangements). Furthermore, this Member State clearly has its currency overvalued in real terms, and it is still subject to considerable financial constriction, while showing vulnerabilities in terms of its export sector (although this is probably the area in which the country is having better results). Above all, the most worrying outcome in the preceding analysis is that inequality has been growing at a blistering pace since the crisis started. Finally, and based on our analysis of the Argentinian and Korean cases, it is clear that exiting the euro would only be a first step, which would have to be accompanied by further structural reforms. The country's credibility to make such reforms is what is at stake here.

74. See Eurostat, Gross Domestic Product Volumes, EC.EUROPA.EU, available at http://epp.eurostat.ec.europa.eu/tgm/table.do?tab=table\&init=1\&language=en\&pcode=teina01 1\&plugin=1 (last visited Apr. 1, 2015) (exhibiting the percentage change, with respect to the previous quarter, in the Gross Domestic Product of the second quarter of 2014). See also Eurostat, First Estimate for the Second Quarter of 2014, EC.EUROPA.EU, available at http:/epp.eurostat.ec.europa.eu/cache/ITY_PUBLIC/2-05092014-AP/EN/2-05092014-AP.

EN.PDF (last visited Apr. 1, 2015) (exhibiting the Euroindicators for the 5th of September, 2014). According to both sources, Germany experienced, in the second quarter of 2014, a growth rate of $-0.2 \%$, France of $0.0 \%$ and Italy a $-0.2 \%$. Id. Italy is therefore technically back into recession, since this is the second consecutive quarter in which this Member State experiences a negative growth rate.

75. See Inflation forecasts, EUROPEAN CENTRAL BANK, available at http:/www.ecb.europa.eu/stats/prices/indic/forecast/html/table_hist_hicp.en.html (last visited Apr. 1, 2015) (according to the ECB's forecasts, the euro-area inflation rate will be of $0.7 \%$ in the third quarter of 2014. Further, the ECB estimates that the euro-area inflation rate will align around $2 \%$ (which is the ECB self-imposed target) not before 2019).

76. In this vein, see Joaquin Almunia, Spanish Commissioner for Competition, Address at the Nueva Economía Forum available at http://www.abc.es/economia/20140929/abci-almuniaalerta-europa-esta-201409291159.html (stating "Europa no está fuera de riesgo de sufrir una tercera recesión" [Europe is not out of risk of suffering a third recession]). 
At a more general level, and based on our previous discussion of the Spanish case, we may create a sort of "determinants checklist" that Member States of the Eurozone might be willing to take into account when or if considering exit. The first question a country has to answer is whether it is sufficiently big, rich, and democratic to afford exit. The second question a country has to answer is how the country fares in terms of its real effective exchange rate, its capacity to borrow on the international markets, and its export prospects. If the country is in a downward spiral as a consequence of an overvalued currency, high external debt, and low export prospects, then time will be an important consideration in this context. The country's ability to make a more even distribution of the costs of the adjustment together with its capacity to make reforms once it is outside the Eurozone should also be included in this equation. 